\title{
Acid-Base Accounting Tests in Combination with Humidity Cells Help to Predict Waste Rock Behavior
}

\author{
Andy Davis $^{1} \cdot$ C. Whitehead ${ }^{1} \cdot$ M. Lengke ${ }^{1} \cdot$ J. Collord $^{1}$
}

Received: 27 August 2018 / Accepted: 15 July 2019 / Published online: 29 July 2019

(c) The Author(s) 2019

\begin{abstract}
Potentially acid-generating (PAG) waste rock is defined in Nevada, USA as material with an acid-base accounting (ABA) ratio $<1.2$, based on the acid neutralizing potential (ANP) to acid generating potential (AGP) ratio. However, waste rock humidity cell tests (HCTs) used to define PAG often fail to release the anticipated acidity. For example, the pH, Fe, and $\mathrm{SO}_{4}$ data from 150 lithology-specific HCTs run on Robinson Mine material for up to 108 weeks supported an empirical 0.3 ABA ratio PAG cut-off. At Turquoise Ridge, the cutoff for 49 HCTs representing current and prospective waste rock was 0.5 ; however, at Mine $\mathrm{C}$, the ABA ratio cutoff for $63 \mathrm{HCT}$ s was 1.6, demonstrating the need for a mine-specific analysis. The ABA ratio cutoff works at these three mines due to a wide range of ANP (e.g. 0.3-963 t of $\mathrm{CaCO}_{3}$ per Kt of waste rock) and AGP (0.3-495 t/Kt waste rock at Robinson). At the Hycroft mine, the 28 HCTs had a much smaller range of ANP (0.3-71 $\mathrm{t} / \mathrm{Kt}$ waste rock) and AGP (3-147 t/Kt waste rock), so no ABA ratio cutoff can be defined. At the Marigold Mine, $31 \mathrm{HCT}$ and 605 paste $\mathrm{pH}$ measurements with an ABA ratio $>0.3$ failed to generate sub-pH 6 leachate. In this case, while the ANP ranged from 0.3 to $230 \mathrm{t} / \mathrm{Kt}$ waste rock, the AGP was too low to develop a plausible ABA ratio cutoff. Post-mortem HCT mineralogy demonstrated pyrite encapsulation in quartz or calcite in waste rock with sub-1.2 ABA ratios, while the surfaces of the "micro-pyrite" particles exhibited secondary rinds of amorphous iron oxide, which may also thwart acidification.
\end{abstract}

Keywords Mineralogy $\cdot$ Pyrite $\cdot$ Encapsulation $\cdot$ Passivation

\section{Introduction}

Acid rock drainage (ARD) continues to emanate from pre467AD Roman-era mines in Europe (Center for Streamside Studies 2000) and has been studied for centuries since Agricola (1556) detailed the mechanics of 16th century mining and its environmental impacts on receiving water bodies. Recently, the topic has been the subject of multi-national treatises (INAP 2009; MEND 2009). However, notwithstanding this extensive body of work, there is still uncertainty as to the relationship between laboratory, field tests, and waste rock acidification at the mine scale. The issues of scale-up from the laboratory to the field has been addressed

Electronic supplementary material The online version of this article (https://doi.org/10.1007/s10230-019-00617-1) contains supplementary material, which is available to authorized users.

Andy Davis

andy@geomega.com

1 Geomega, 2585 Central Ave, Boulder, CO 80301, USA elsewhere (e.g. Eary 2015; Maest and Nordstrom 2018; Smith et al. 2009).

Waste rock facilities that contain hundreds of millions of tonnes of rock present an enormous environmental liability in the event of acid generation. If geochemically stable waste rock facilities can be constructed with minimal stipulations on waste rock sequencing and routing (i.e. maximum flexibility), then cost savings can help extend the life-of-mine. However, profit margins will shrink along with the life-ofmine if waste rock haul distances are not optimized, because haulage accounts for up to 50\% of the cost of mining (Oraee and Goodarzi 2007). Consequently, differentiating between potentially acid generating (PAG) and non-potentially acid generating (non-PAG) waste rock has important environmental and fiscal implications.

One interpretation of PAG and non-PAG waste rock comes from the regulatory definition in Nevada, USA (where the mines described in this paper are located), which is based on the acid neutralizing potential (ANP) and the acid generating potential (AGP). The rock is deemed non acid-generating if the ANP/AGP [the acid base accounting 
(ABA) ratio, also referred to as the neutralizing potential ratio (NPR)] is $>1.2$ for non-PAG materials (NDEP 2014). In contrast, INAP (2009) suggests that waste rock may be PAG if ANP/AGP $<1$, non-PAG if ANP/AGP $>2$, and uncertain in between. Most US mining permits specify that waste rock with an ABA ratio $<1.2$ be managed separately from run-of-mine waste rock, typically requiring emplacement in a PAG cell, which may require a liner or other special handling, thereby incurring additional material handling costs. Mines with abundant PAG waste rock, especially if mined from deeper in the pit and later in the life-of-mine, may face additional expenditures to encapsulate it within non-PAG material (i.e. additional haulage costs from moving non-PAG stockpiles).

Consequently, there have been extensive efforts to predict materials characteristics (e.g. for waste rock, tailings, and pit highwalls) that will facilitate ARD onset, with many contributions evaluating the efficacy of kinetic test work (e.g. Brough et al. 2017; Maest and Nordstrom 2018; ParbhakarFox et al. 2013; Weber et al. 2006) as a predictor of ARD. Comprehensive approaches using multiple tests have also been suggested by Morin and Hutt (1998) and by ParbhakarFox and Lottermoser (2015). Whichever approach is deemed appropriate, collecting representative samples is the first step in developing meaningful waste rock characterization (Brough et al. 2013; Parbhakar-Fox and Lottermoser 2015).

The goals of this investigation were to determine if there is a site-specific, empirical ABA ratio that provides a criterion for a PAG/non-PAG cutoff, and if mineralogy may help explain why some kinetic tests with $\mathrm{ABA}$ ratio $<1.2$ fail to generate acidity. We compared humidity cell test (HCT) effluent $\mathrm{pH}$ to the ABA ratio to determine if these tests (Supplemental Tables 1 through 5) provide the predictive ability to identify which materials generate ARD (defined here as a leachate with a second lowest $\mathrm{pH}<6$ over the duration of the HCT). While distilled water may have a lower $\mathrm{pH}$ (5.5),
pH 6 was selected as a working definition of the onset of HCT acidification.

To date, there appears to be no analysis using a multimine site HCT population based on the relationship between the kinetic test results and the ABA ratio, and only one other contribution analogous to this work (Prestia et al. 2013). In that case, contrary to our study, while a relationship was observed between the net acid generating (NAG) test and HCTs, no causal relationship was apparent between the ABA ratio and HCTs at the Hycroft mine, NV. However, at that time, those authors only had 15 HCTs at their disposal. Subsequently, 11 additional HCTs were run for a longer period, so the entire 26 HCT data set has been evaluated in this paper.

\section{Mine Settings}

Data were available from five mines, all in Nevada: (1) the Robinson mine, Ely, (2) Turquoise Ridge (TR) in the Kelly Creek basin, (3) Mine C, (4) the Hycroft mine, and (5) the Marigold mine near Battle Mountain. The Robinson and Mine $\mathrm{C}$ are copper mines, Hycroft and Marigold are open pit gold mines, and TRJV is an underground gold mine (Table 1).

\section{Robinson Mine, Ely Nevada}

The Robinson porphyry copper district has been mined for over 100 years, resulting in three pits, Liberty, TrippVeteran, and Kimbley/Ruth, where mining is currently focused (Fig. 1). Until 2015, the 1.2 ABA ratio criterion was applied at the Robinson Mine to segregate PAG from non-PAG waste rock. In 2015, a waste rock management plan for the Robinson mine proposing an ABA ratio cutoff of 0.3 was accepted by the Nevada Dept. of Environmental Protection (NDEP 2015a).
Table 1 Mine and material characterization summary

\begin{tabular}{llllll}
\hline Mine information & Robinson & TR & Mine C & Hycroft & Marigold \\
\hline Annual precipitation $(\mathrm{cm})$ & 20 & 33 & 20 & 19 & 28 \\
Annual evaporation $(\mathrm{cm})$ & 100 & 67 & 50 & 150 & 114 \\
Ore type & $\mathrm{Cu}$ & $\mathrm{Au}$ & $\mathrm{Cu}$ & $\mathrm{Au}$ & $\mathrm{Au}$ \\
Mine type & $\mathrm{Pit}$ & Underground & $\mathrm{Pit}$ & $\mathrm{Pit}$ & Pit \\
Geology & Porphyry & Carlin type & Porphyry & Volcanic & Oxide \\
& & & \multicolumn{2}{c}{ acid-leached } \\
Mineralogy available & Yes & Yes & Yes & No & No \\
Static test data & & & & $3.4-147$ & $0.3-42$ \\
AGP $(\mathrm{TCaCO} / \mathrm{KT})$ & $0.3-495$ & $0.3-364$ & $0.8-173$ & $0.3-230$ \\
ANP $(\mathrm{TCaCO} / \mathrm{KT})$ & $0.3-662$ & $1.1-919$ & $-0.74-684$ & $0.3-71$ & $-24-228$ \\
NNP $(\mathrm{TCaCO} / \mathrm{KT})$ & $-226-660$ & $-349-919$ & $-165-684$ & $-146-49$ & 252 \\
NNP range & 886 & 1268 & 849 & 195 & 31 \\
HCTs & 150 & 49 & 61 & 26 & \\
\hline
\end{tabular}




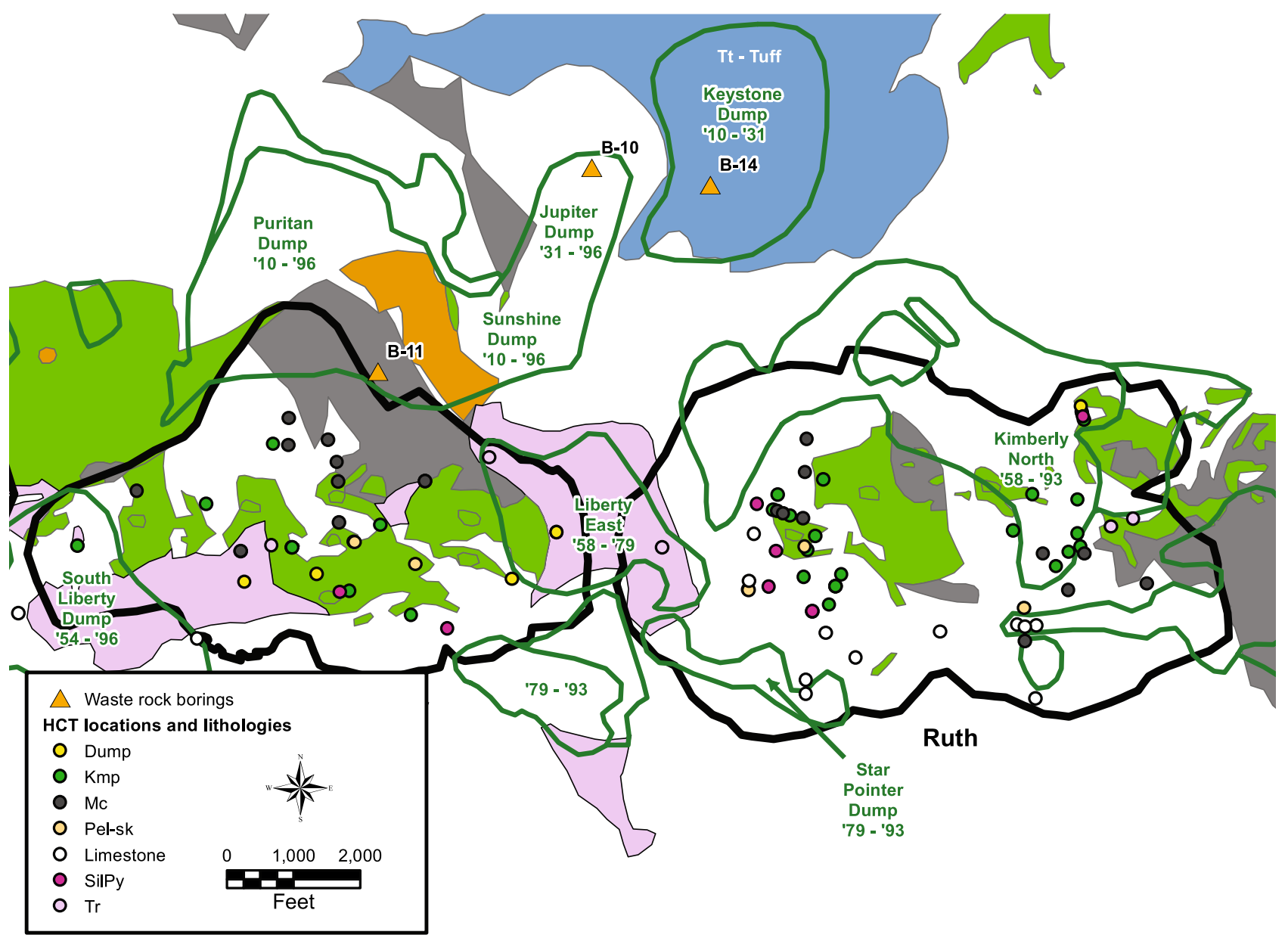

Fig. 1 Surface geology in the Liberty/Ruth pit area at the Robinson mine, on which are superimposed lithology-specific HCTs, the waste rock dumps and their years of construction, and the boring locations

The ore at Robinson mine is hosted in intrusive monzonite porphyry (Kmp) surrounded by limestone (Pel and $\mathrm{Dg}$ ), sandstone with intercalated limestone (Prh and Pal), shale (Mc and Dp), and rhyolite (Tr). There has been alteration of the Pel near the intrusive to skarn and silica pyrite. Further mining through 2022 will generate 218 million (MM) tonnes (T) of waste rock distributed among:

- Pennsylvanian Ely Limestone [Pel (22\%) and altered/ silica-pyrite; SilPy (6\%) or skarn (Pel-Sk, 7\%)],

- Mississippian Chainman Shale (hornfels and skarn) (Mc, 13\%),

- Permian Rib Hill Sandstone (Prh, 13\%),

- Cretaceous quartz monzonite porphyry (Kmp, 12\%),

- Tertiary rhyolite ( $\mathrm{Tr}, 4 \%)$, and

- Dump or rubble slides from within the pits. (profiles on Fig. 11). The pit shapes and dumps overlap because the dumps were later mined out with pit expansion. The Ruth pit area is shown on Fig. 4

Pyrite can be identified in all of the formations encountered as waste rock, but most of the PAG waste rock will be derived from Kmp, SilPy, and Mc. All of the rock types in the Robinson mining district have a large, insoluble, silicarich component, which in the case of plagioclase and potassic feldspars, may be a long-term source of ANP (Desborough et al. 1998). Furthermore, the abundance of limestone (e.g. Pel) inhibits the onset of acidification by providing buffering capacity and facilitating ferrihydrite precipitation (Caldeira et al. 2003), while Prh also contains interbedded carbonate.

\section{Turquoise Ridge (TR)}

TR is located approximately $45 \mathrm{~km}$ north of Golconda NV, where there has been mining since the late-1930s. Beginning in 1994, the Getchell underground mine was excavated from the base (1422 m amsl) of the Getchell Main pit through 
three adits in the western pit wall, resulting in $\approx 42 \mathrm{~km}$ ( 26 miles) of underground workings extending beneath the pit to $\approx 1320 \mathrm{~m}$ amsl. The adjacent TR underground mining operations began in 1996. Mining ceased after the first quarter of 2008 at the Getchell area, whereas mining at the TR underground is projected to continue until 2041.

The TR mine complex lies along the large-displacement Getchell fault at the eastern foot of the metamorphic and sedimentary Osgood Mountains. Local mineralization in the Carlin-type gold deposit is primarily hosted within a sequence of Cambrian-Ordovician carbonate and clastic rocks, containing interlayered basalts that historically have been mapped as the Cambrian Preble, Ordovician Comus, and Ordovician Valmy formations.

The ore grade is most closely correlated with the abundance of fine-grained, gold-bearing arsenian pyrite associated with variable amounts of decalcification, argillization, and silicification (Cline et al. 2008). However, multiple overprinting of hydrothermal events complicates the establishment of a coherent time-space model for the local Carlintype mineralization.

During open pit mining, the exposed formations consisted of the Preble, a thinly bedded limestone interbedded with carbonaceous shale (Roswell et al. 1979), and the overlying Comus formation, consisting of carbonaceous and calcareous shale, limestone, and volcanics. This sequence is bounded by a thrust fault that separates the Preble Formation from the Valmy (basalt, shale, chert, and quartzite; Berger and Taylor 1980).

The current underground TR mine is hosted primarily in the Ordovician Comus formation. The associated waste rock was recently reclassified, with $\approx 4.9 \mathrm{MM}$ t of waste rock comprising Oc5 (limestone with thinly laminated mudstone), $\approx 0.24 \mathrm{MM} t$ of NPB (north pillow basalt), $0.15 \mathrm{MM} t$ of Oc 2/3 (laminated mudstone and siltstone), 0.15MM t DACR (rare earth dacite), and 0.05MM t Oc6 (75-90\% limestone with mudstone).

\section{Mine C, Northeastern Nevada}

This porphyry copper deposit is hosted in the Battle Formation proximal to an igneous contact. There are varying degrees of alteration types ranging from potassic, pyritic, silicic, and propylitic through sericitic. The regional geology consists of Cambrian and Ordovician siliceous and volcanic rocks unconformably overlain by Pennsylvanian and Permian Antler sequence rocks, with the Pennsylvanian and Permian Havallah sequence thrust over the Antler sequence from the west. Tertiary intrusive rocks cut the Paleozoic rocks, and Tertiary ash-flow tuffs and basalt flows occur locally.
Three principal units, the Pumpernickel (25\%), Harmony (21\%), and Battle (31\%) formations will contribute $77 \%$ of the $\approx 2$ billion $t$ of waste rock. The Pumpernickel Fm is composed of interbedded argillite and chert, with minor greenstone flows and pyroclastics. The argillite is mainly gray, green, or reddish-brown and grades laterally into siliceous argillite and black, green, or red chert. The Harmony Fm is comprised of: interbedded, greenish-brown micaceous sandstone; feldspathic sandstone; arkose; and green, red, or black shale with minor amounts of calcareous shale and limestone. Where metamorphosed by granite intrusives, the shale to dark hornfels contains pyrite veins.

The Battle formation comprises three units. The lower unit is $\approx 122 \mathrm{~m}$ ( $400 \mathrm{ft}$ ) of coarse conglomerate with quartzite, chert, limestone, greenstone, and sandstone pebbles, cobbles, and boulders with sandy and shaly partings. The middle unit is $\approx 22 \mathrm{~m}$ ( $75 \mathrm{ft}$ ) of interbedded pebble conglomerate, sandstone, shale, limy shale, and limestone and the upper unit is $\approx 76 \mathrm{~m}$ ( $250 \mathrm{ft}$ ) of interbedded pebble conglomerate, sandstone, shale, and calcareous shale.

\section{Hycroft}

This silver/gold mine is located in the "Sulfur District" at the edge of the Black Rock Desert in northwestern Nevada and hosted in the extruded breccias and conglomeratic volcanics associated with the Tertiary Kamma Mountain volcanic event (Ebert and Rye 1997). The volcanics are predominantly acidic to intermediate tuffs, flows, and coarse volcaniclastic rocks. Downward percolation of acids resulted in vertical sequencing of an acid leached oxide zone, where sulfides were altered to iron oxide, and a hypogene, silicic oxide zone over a low-grade gold silica sulfide zone (Wilson 2010). The shallow geothermal system resulted in extensive leaching of the rock, resulting in a porous matrix dominated by silica (Prestia et al. 2013).

Acid leach alteration during the later stages of mineralization resulted in dissolution of the rock matrix and reprecipitation of acid sulfates, e.g. alunite and jarosite. Propylitic alteration is represented by chlorite, quartz, potassium feldspar, calcite, and pyrite, while the acid leach material contains cinnabar, realgar, and native sulfur (as late stage massive veins or disseminations), with opal and gypsum as accessory minerals (Wilson 2010).

\section{Marigold}

The Marigold gold mine is $\approx 5 \mathrm{~km}$ south of Valmy, Nevada, northwest of the Battle Mountain Range. Mining started in the area in the 1920 s, with modern day mining resuming in 1988. The mine is located along the Golconda Thrust, which trends approximately north-south and is the dominant structural control in the area. Mineralization occurred during 
the Eocene-Oligocene eras (38-41 Ma) and is associated with felsic intrusions (Stewart et al. 1986). The Havallah Sequence, Antler Sequence, Valmy Formation, and Quaternary alluvium are the primary waste rock generating lithologies at Marigold.

The Havallah Sequence mineralogy is characterized by quartz and calcite, with smaller quantities of hematite, clays, feldspar, barite, goethite, and pyrite. The limestone and siltstone of the Antler Sequence contain calcite, quartz, clays, and lesser amounts of goethite and barite. The Ordovician Valmy minerals include quartz, goethite, clinochlore, plagioclase, and dolomite. The alluvium commonly exhibits caliche. While the deposit is primarily oxide, mine expansion will intersect the transitional zone above the sulfide (Fig. 2). About $930 \mathrm{MM} \mathrm{t}$ of waste rock will be generated, primarily comprising Valmy (54\%), with smaller quantities of Havallah (24\%), Antler (13\%), and alluvium (6\%).

\section{Methods}

\section{Sample Selection}

Exploration samples are first analyzed for whole rock analysis, in which the sample is digested in aqua regia (US EPA 1996) and the solution analyzed by ICP (or ICP-MS) for a suite of elements. Each mine's exploration database typically contains a large number (thousands) of $\mathrm{Ca}, \mathrm{Mg}$, and $\mathrm{S}$ analyses as well as geochemical (e.g. $\mathrm{Al}, \mathrm{Fe}, \mathrm{Mn}$ ) and ecological risk parameters (e.g. As, $\mathrm{Sb}, \mathrm{Tl}, \mathrm{Hg}$ ) on intervals from bores drilled into and through the deposit (e.g. 48,298 $1.5 \mathrm{~m}$ core intervals at Robinson). Using kriged assignments for $\sum \mathrm{Ca}+\mathrm{Mg}$ as a proxy for the neutralizing capacity (calcite and/or dolomite) and $\sum \mathrm{S}$ to represent the sulfide acid generating capacity, an ABA ratio block model can be constructed on $15 \times 15 \times 15 \mathrm{~m}$ blocks with centroids in the mining waste rock envelope (e.g. 4,667 blocks for Robinson) that identify the types (lithology) of waste rock that will be mined, and the range of ABA values for each lithology. A preliminary proxy ANP value is calculated based on the $\mathrm{Ca}$ and $\mathrm{Mg}$ content (Eq. 1) and a proxy AGP value determined from sulfur (Eq. 2).

proxy $\mathrm{ANP}\left(\mathrm{kg} /\right.$ tons $\left.\mathrm{CaCO}_{3}\right)=25 \times \% \mathrm{Ca}+34.7 \times \% \mathrm{Mg}$.

proxy $\operatorname{AGP}\left(\mathrm{kg} /\right.$ tons $\left.\mathrm{CaCO}_{3}\right)=31.25 \times \% \mathrm{~S}$.

The proxy AGP (Fig. 3a) is combined with the proxy ANP (Fig. 3b) to determine the net neutralizing potential (NNP, i.e. ANP-AGP) and the ABA ratio (ANP/AGP). These preliminary depictions are overestimates, because $\mathrm{Ca}$ will be present in feldspars as well as carbonate, $\mathrm{Mg}$ in pyroxene as well as dolomite, and $\mathrm{S}$ in sulfates as well as sulfides. Output from the proxy ABA ratio model (Fig. 3c), coupled with the lithology (Fig. 1) can be used to determine the tonnages and range of ABA values associated with each lithology. For Robinson, the 5th percentile of the $15 \mathrm{~m}$ composite blocks was ANP:AGP $=0.051$; $\mathrm{NNP}=-314 \mathrm{t}$ of $\mathrm{CaCO}_{3} / \mathrm{Kt}$, while the 95 th percentile was $\mathrm{ANP}: \mathrm{AGP}=548 ; \mathrm{NNP}=495 \mathrm{t}$ of $\mathrm{CaCO}_{3} / \mathrm{Kt}$.

\section{Static Testing}

From the thousands of ICP data points, a subset of samples were selected for static testing by the Nevada modified Sobek (NMS) method (NDEP 2015b) to quantify the ANP, AGP, NNP, and ABA ratio for each sample, which was then compared against the proxy model results. Samples for ABA were selected to represent the spatial and geochemical variability of the lithologies relative to the proposed waste rock envelope volumes for the waste rock management plans.

In the NMS method, the S fraction consists of: (1) total sulfur, (2) hot water soluble acid sulfate extractable $S$, (3) hydrochloric acid $(\mathrm{HCl})$-extractable sulfate, (4) nitric acid $\left(\mathrm{HNO}_{3}\right)$-extractable sulfide, and (5) the residual organic sulfur content, with the AGP defined as the sum of fractions 2 and 4 . The ANP was determined by reacting the sample with $\mathrm{HCl}$ and titrating the residual $\mathrm{HCl}$ to a circumneutral end-point, measuring only the neutralizing capacity that was consumed under the test conditions.

ABA methods have evolved over the last 20 years of data collection, so it is useful to compare ABA analysis at the mine production level with the methods acceptable to permit mines. The mines require $\mathrm{ABA}$ ratio data on a rapid turnaround to discriminate between PAG and non-PAG, so that waste rock is deposited in the correct locations. Over the last 25 years, the net carbonate value (NCV) quantified using a Leco analyzer (ASTM 2007) has been used at the mine-scale. The Leco method differs from the ABA method in that the Leco instrument measures total inorganic $\mathrm{C}$ and total S. This measurement is blind to both sulfur speciation and the effects of grain size on chemical reactivity.

Permitting follows a different trajectory, where the ABA ratio is typically quantified in Nevada (where all the mines are located) using the NMS method. The NCV and NMS methods provide similar results (Fig. 4), with the correlation coefficient for the 99 samples (0.87) statistically significant at the $\mathrm{p}<1 \%$ level, showing that the NCV method is a good analog to the NMS method. Consequently, the mine-specific NCV data are a reasonable surrogate for the NMS results and vice versa.

Validation of the proxy ABA ratio model assignments compares the NMS ANP and AGP values with the ICP $\mathrm{Ca}+\mathrm{Mg}$ (Fig. 5a) and S (Fig. 5b) respectively. 

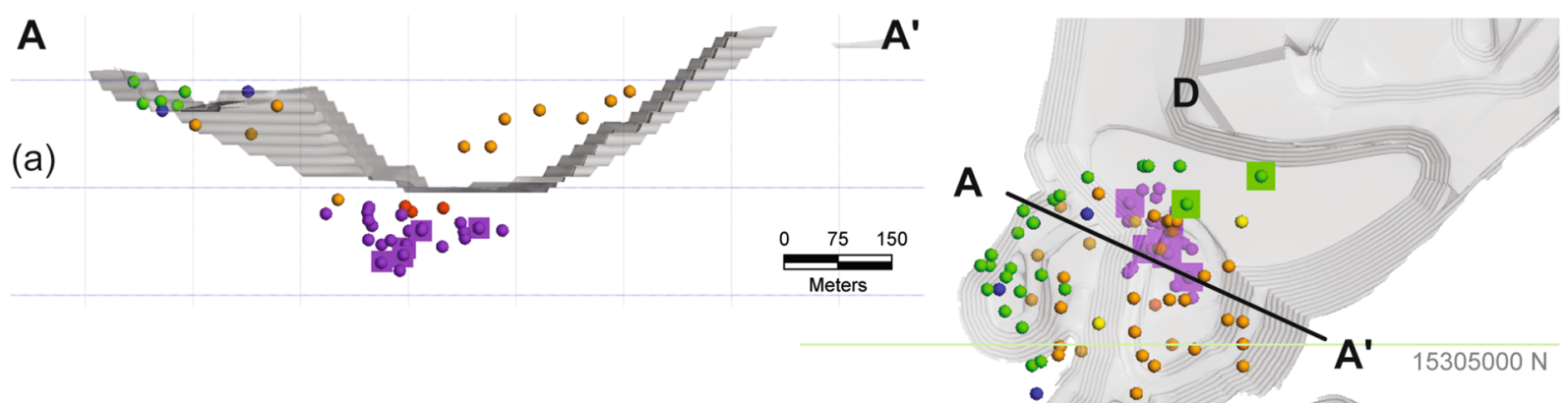

Formation
Alluvium
Antler
Havallah
Cretaceous-Tertiary intrusive
Valmy oxide
Valmy transition
Valmy sulfide

B

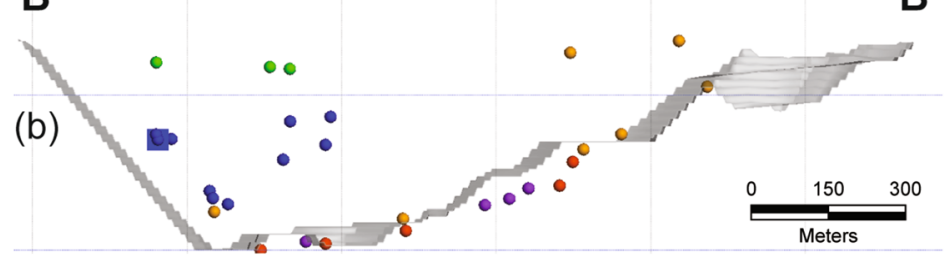

B'

B

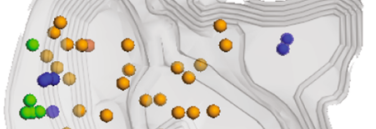

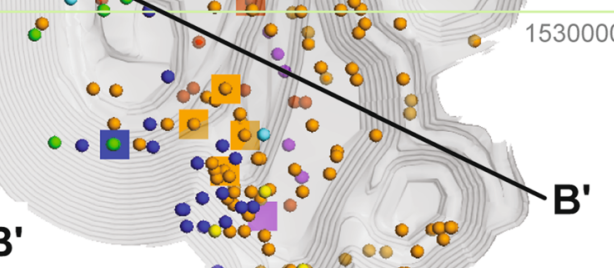
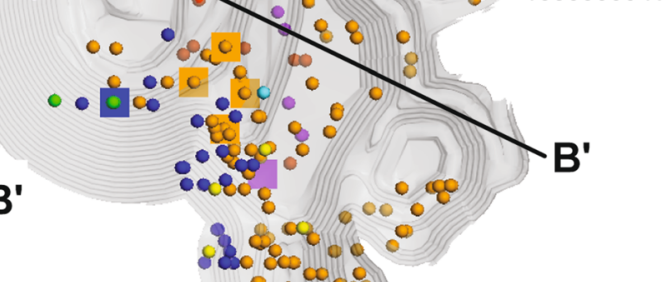

- ico cald
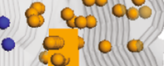

rocal ad

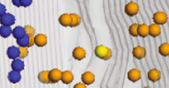

$\cos \theta y$

- 8

- $80^{\circ}$

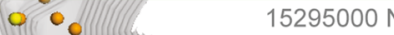

C

(c)

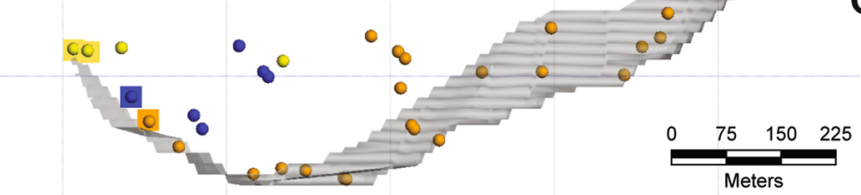

$\stackrel{\infty}{C^{\prime}}$

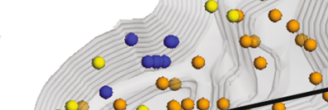

$C^{\prime}$
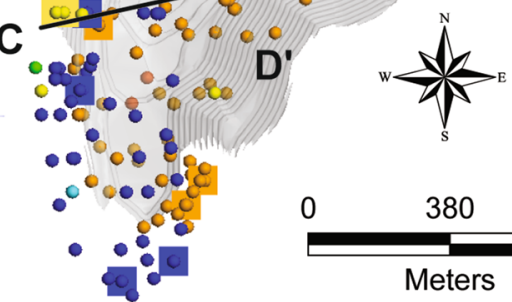

0

380

760

Meters

Nevada State Plane west (m).

Fig. 2 The Marigold mine showing the spatial distribution of static (filled circle) and HCT (filled square) samples. The cross-sections (a-c) show sample locations in relation to the future waste rock envelopes 
Fig. 3 Example of, a kriged $\mathrm{AGP}\left(\mathrm{t}\right.$ of $\mathrm{CaCO}_{3} / \mathrm{Kt}$ of waste rock) based on $\mathrm{S}$, b kriged ANP (t of $\mathrm{CaCO}_{3} / \mathrm{Kt}$ of waste rock) based on $\mathrm{Ca}+\mathrm{Mg}$, and $\mathbf{c}$ the computed ANP/AGP (ABA ratio; unitless) from the Ruth pit exploration database (at Robinson). The location of Ruth pit is shown on Fig. 1
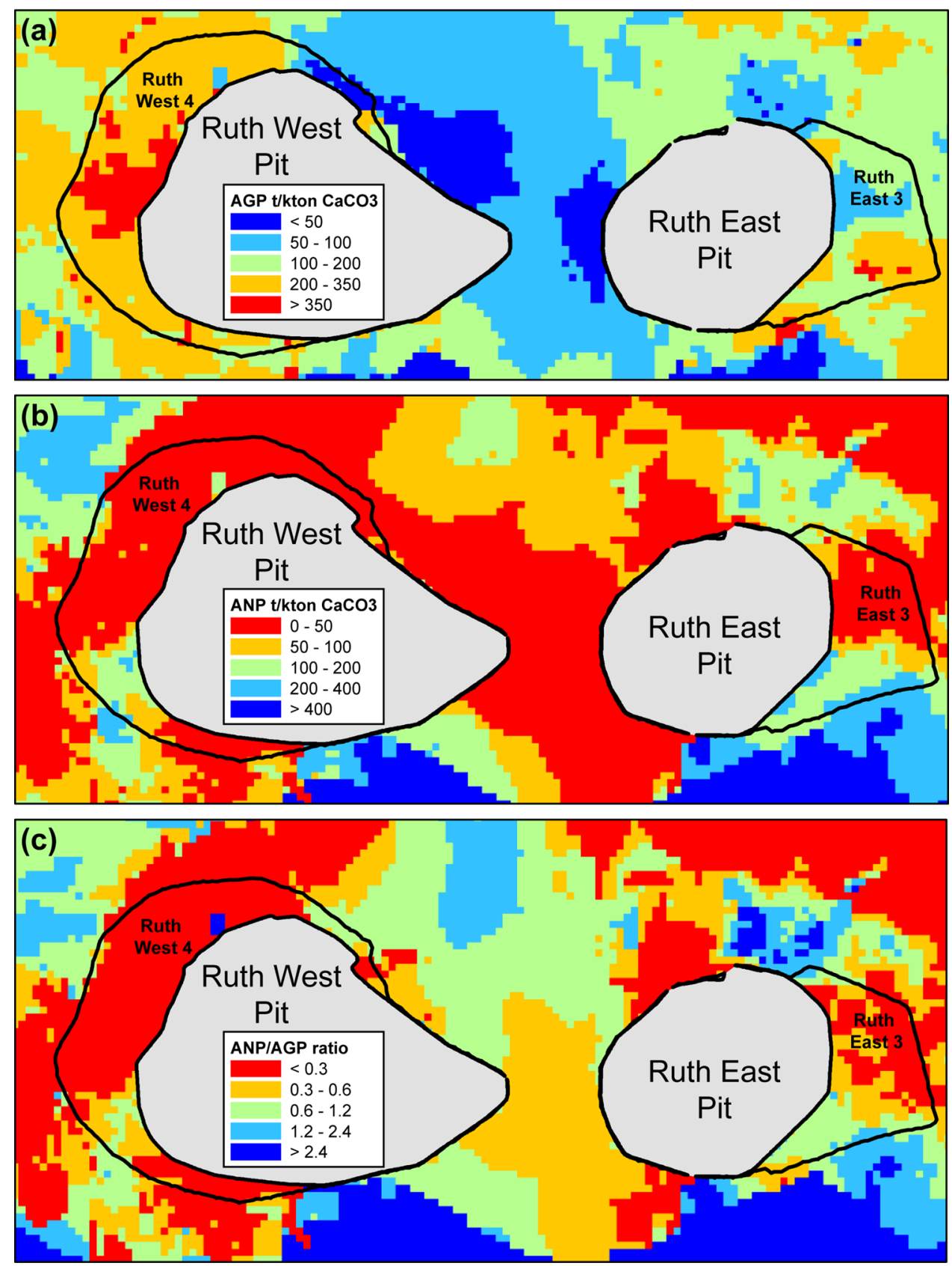

\section{Kinetic Tests}

The number of HCT samples is based on the goal of spatial (Figs. 1 and 2) and comprehensive indicator parameter (IP) concentration coverage. The objective is for the HCTs to represent both the concentration range and the cumulative frequency distribution (CFD) of the IPs (Fig. 6). If gaps in coverage are identified, the model can be used to identify existing or future borehole rejects to provide additional samples.

\section{Humidity Cell Tests (ASTM D5744)}

HCTs are run for a minimum of 20 weeks (ASTM 2012) and sometimes for several years (INAP 2009), depending on the goals of the study. Each cell is charged with $1 \mathrm{~kg}$ of minus $6.3 \mathrm{~mm}$ material and on day 1 (week 0 ) leached with $1 \mathrm{~L}$ of deionized (DI) water and analyzed at the bench for $\mathrm{Ca}, \mathrm{SO}_{4}$, $\mathrm{Fe}^{2+} / \mathrm{Fe}^{3+}$, alkalinity (or acidity), and $\mathrm{pH}$. Subsequently, dry air is passed through the cell for 3 days, followed by 3 days of moist air. On the seventh day, another liter of DI water is 
Fig. 4 Comparison between NNP from the NCV and the Nevada modified Sobek methods for multiple lithologies. $\mathrm{MC}=$ coarse rejects and $\mathrm{HCT}=$ pre-run humidity cell charges for four formations (a-d)

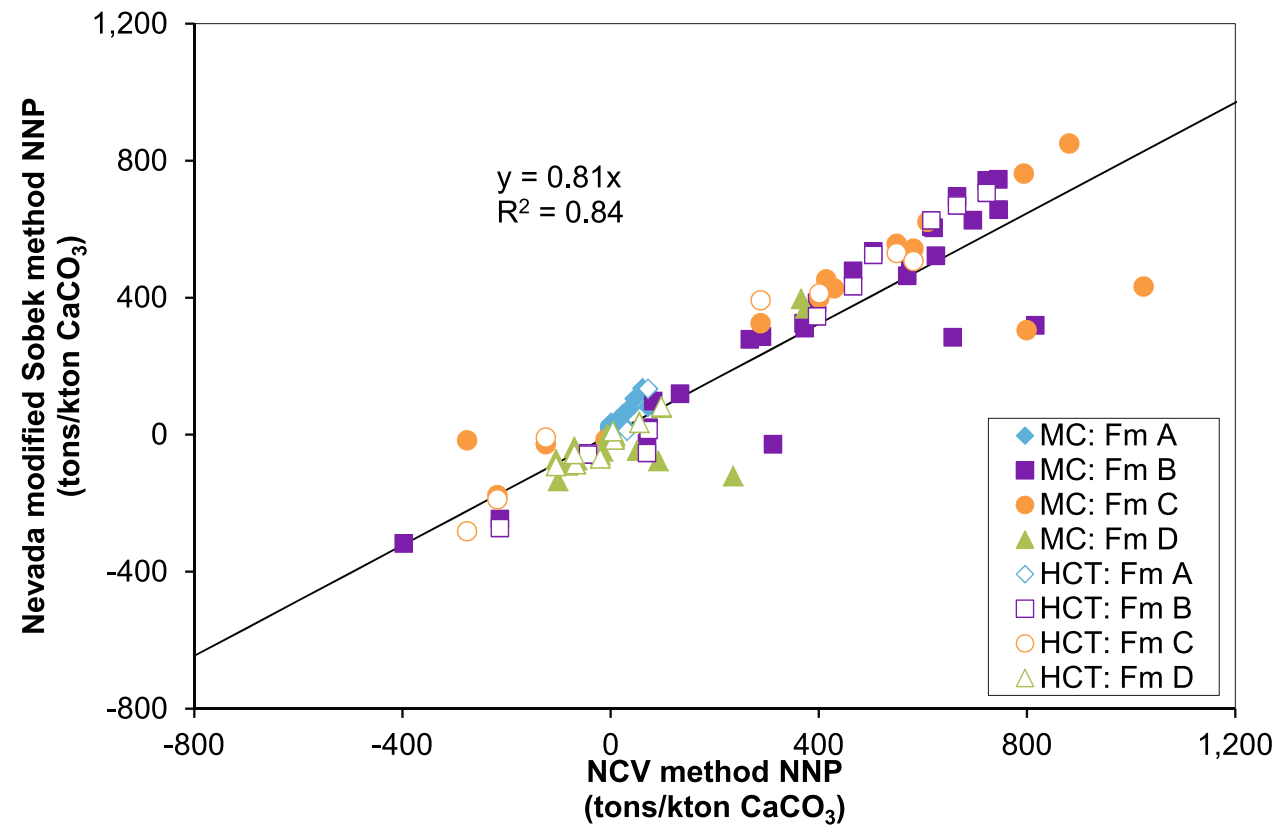

(a)

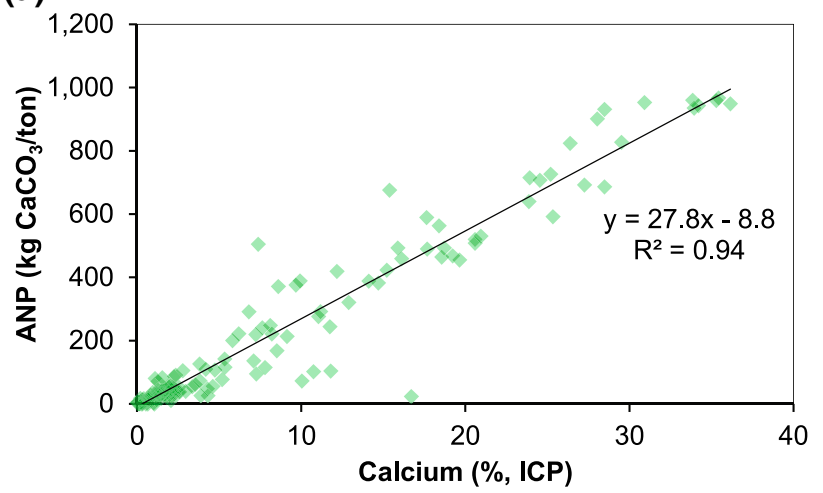

(b)

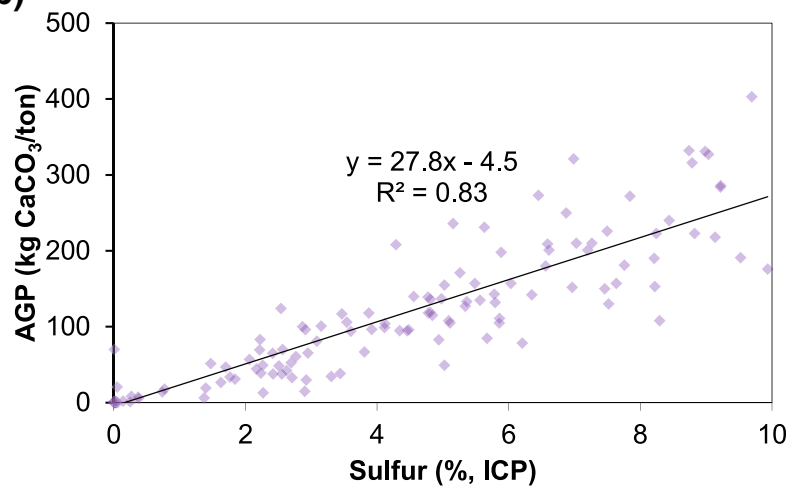

Fig. 5 a Correlation of measured ANP by NV-modified Sobek with whole rock Ca by ICP, and $\mathbf{b}$ correlation of measured AGP by NVmodified Sobek with whole rock S by ICP (constrained by detection limit to $<10 \% \mathrm{~S}$ ) passed through the cell and analyzed. This process continues weekly. Metals and major ions released into the leachate are typically measured at $0,1,2,4,8,12,16$, and 20 weeks, and every 4 weeks thereafter.

There were 150 HCTs run on Robinson samples between 1993 and 2016 (95 for over 2 years and the remainder for 20-101 weeks). This population (Supplemental Table 1) included HCTs that represent: (a) samples with clearly identifiable lithologies (86, Fig. 1), (b) dumps (23, including 14 dump face composites), and (c) composites or blends representing non-unique materials (41).

Of the 73 TR HCTs run for 52-108 weeks (Supplemental Table 2), 49 are pertinent to the current and future waste rock envelope around the underground workings that will be mined, and the waste rock that will be placed on the existing facilities through 2039. A total of 61 HCTs were run from Mine C, 23 in 2008 and 38 in 2012 (Supplemental Table 3), with durations of 32-87 weeks.

Two sets of HCTs were run from Hycroft, the first 15 for 80-100 weeks and an additional 11 for 40 weeks (Supplemental Table 4) on waste rock described as sedimentary or volcanic with argillic, acid leach, silicic, or propylitic alteration. Thirty-one HCTs were run from Marigold (Supplemental Table 5) proportional to the distribution of the mined lithologies, e.g. 61\% Valmy (19 samples), which hosts the redox boundary transition, $19 \%$ Antler (7 samples), 13\% Havallah (3 samples), and 6\% alluvium (2 samples), representing the range of waste rock that will be encountered during mining (Fig. 2).

Morin and Hutt (1998) caution that if kinetic tests are not run long enough, that the materials may incorrectly be deemed non-acid generating. However, humidity cells are 
Fig. 6 Humidity cells (purple lines) selected based on static test population statistics for indicator parameters (the grey histogram bars) for $\approx 15,000$ samples from the Oc5 lithology at the TRJV mine. The blue line represents the cumulative frequency distribution (CFD) of the drillhole data. The HCTs cover $>95 \%$ of the CFD
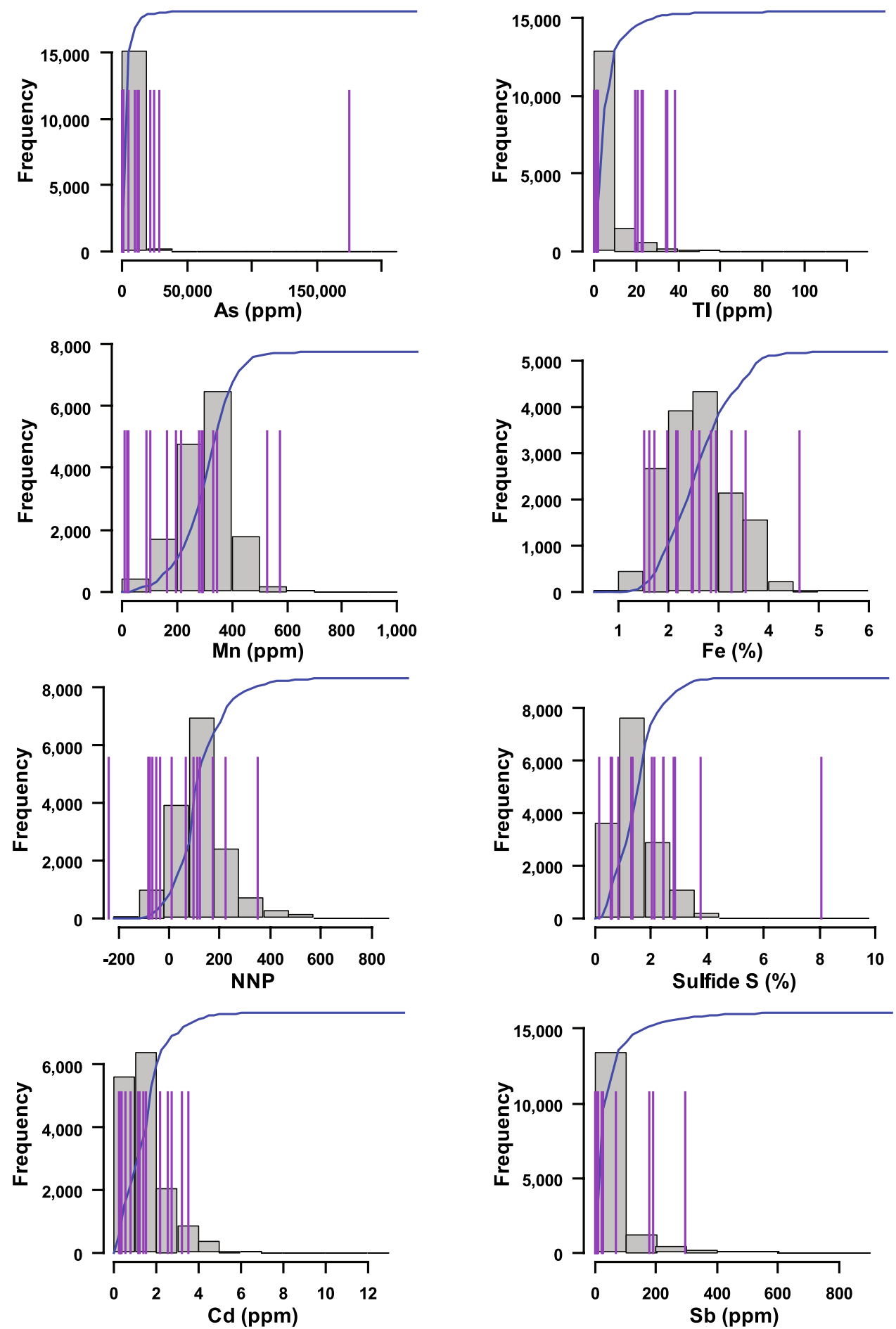

designed as a worst-case analog to accelerate weathering reactions by exposing waste rock (or other material) to abundant $\mathrm{O}_{2}$ and moisture, and to replicate the longer-term potential of exposed materials to generate/consume acid, while providing quantifiable trends of temporal solute production. Even during the dry air portion of the cycle, 10-15\% moisture by weight of the HCT remains, further facilitating sulfide oxidation (Supplemental Table 6).
In addition, these concerns also assume that all sulfide is reactive, but mineralogic constraints due to silicatehosting (Dold 2017) and oxide coating of pyrite (Caldeira et al. 2003) demonstrate that not all pyrite is available to react. Finally, the objective is to manage risk and the HCTs correlated operationally to the ABA ratio are accepted by regulatory agencies as a plausible method to achieve this goal. While there may be sporadic samples that take 
decades to generate acid in HCTs, most generate acid within 20-50 weeks if they have a predilection to do so. Maest and Nordstrom (2018) advocate that HCTs be run for at least a year. Some of the cells in the five data sets were run for up to 136 weeks (Supplemental Tables 1 through 5), while most were run for more than a year.

\section{HCT Mineralogy}

Selected HCTs were subjected to mineralogy to investigate the starting condition. Mineralogy was available for HCT samples from Robinson, TR, and Mine C, but not from Hycroft or Marigold.

At Robinson, electron microprobe analysis (EMPA) followed the method of Davis et al. (1992). Briefly, the sample was mounted in an epoxy mold, allowed to cure at room temperature, and polished at low speed using kerosene to prevent dissolution of water-soluble phases. The surface of the mold was then cleaned with isopropyl alcohol and coated with a thin layer of carbon to allow electrical conductance. Metal-bearing particles were identified using a combination of energy dispersive spectroscopy, wavelength dispersive spectroscopy, and backscatter electron image spectroscopy (BES). Particle images were obtained using BES and recorded as photomicrographs. The elemental composition of the material was established relative to EMPA standards to determine the stoichiometry of solid metal phases in the sample.

For TR, a split of each HCT charge was stage-crushed to $90 \%$ passing $850 \mu \mathrm{m}$, and then further split to obtain representative aliquots for mineral liberation analysis (MLA). The representative splits were embedded in epoxy resin and polished until grains were exposed. Polished sections were quantitatively analyzed by MLA using an FEI Quanta 600F scanning electron microscope (SEM).

Minerals and other attributes were directly measured on the MLA using a combination of image analysis employing atomic number contrast imaging (from backscattered electrons, or BSE-signal intensity) and energy dispersive spectrometry (EDS) using two Bruker 5010 SDD detectors. BSE signal intensity is proportional to the mineral mean atomic number. The Field Emission Gun MLA was set at an accelerating voltage of $25 \mathrm{kV}$ and a spot size of 6 . Selected samples were measured in the XBSE-STD mode to collect reference mineral spectra. XMOD measurement was run on all samples to characterize modal mineralogy.

At Mine C, 25 pre-run HCT sample splits collected in 2008 were analyzed by semi-quantitative XRD using Rietveld refinement and whole pattern fitting and quantitative mineral liberation analysis (X-ray MLA). Prior to examination by SEM/EDS and MLA, samples were embedded in epoxy, polished, and carbon coated. Approximately 30,000 (a)

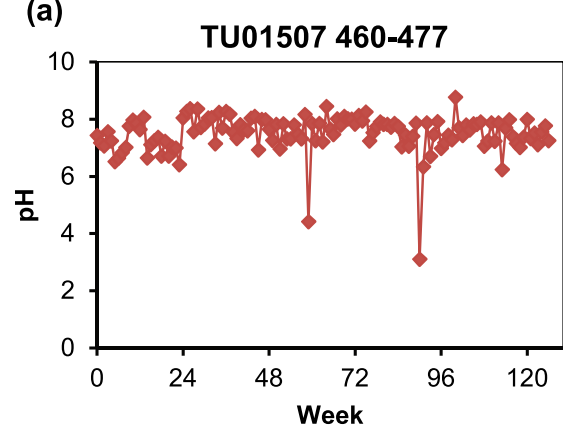

(d)

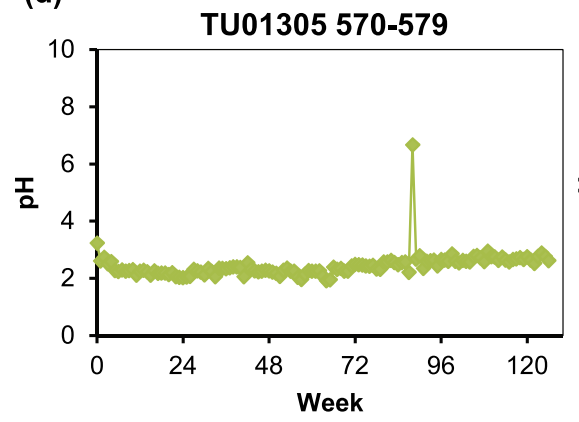

(b)

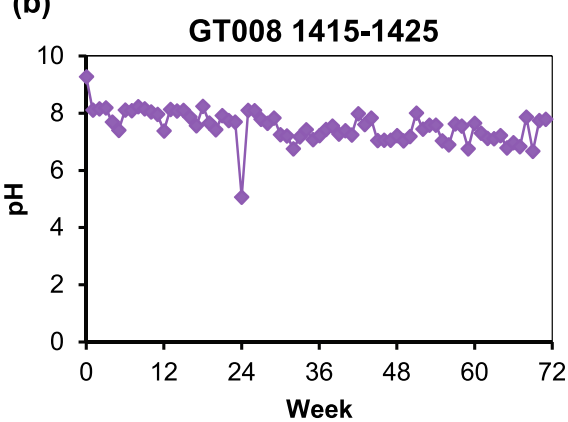

(e)

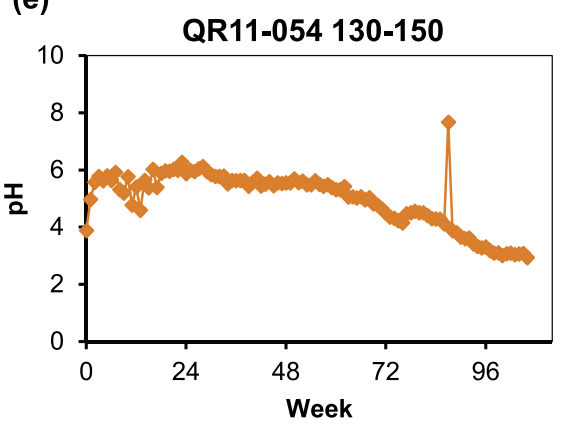

(c)

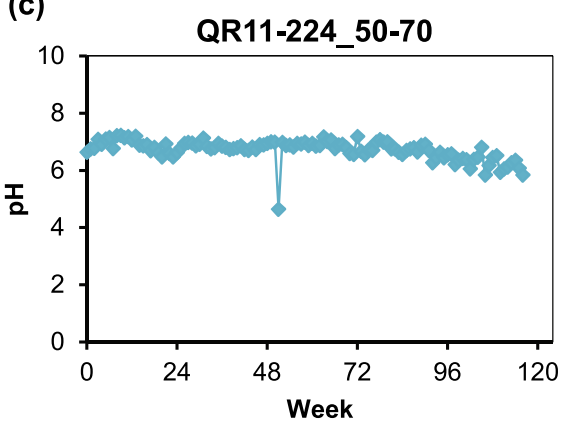

Fig. 7 HCT leachate long-term alkaline $\mathrm{pH}$ trends in $(\mathbf{a}-\mathbf{c})$ with anomalous acid $\mathrm{pH}$ measurements inconsistent with the ABA ratios of 43.6 (a) and 19.9 (b). There are sporadic alkaline pH measure- ments in $(\mathbf{d}, \mathbf{e})$, despite long-term acidic trends and ABA ratios of 0.0 and 0.03 , respectively 
EDS analyses were obtained from each sample, and the spectra compared with standards. Since XRD detection limits for quantification are generally $>1 \%$, MLA was used to quantify trace $(<1 \%)$ minerals and sulfides.

\section{Results}

Humidity cell leachate $\mathrm{pH}$, measured on a weekly basis, typically follows trends that change by no more than a unit from week to week. Over the course of analyzing several
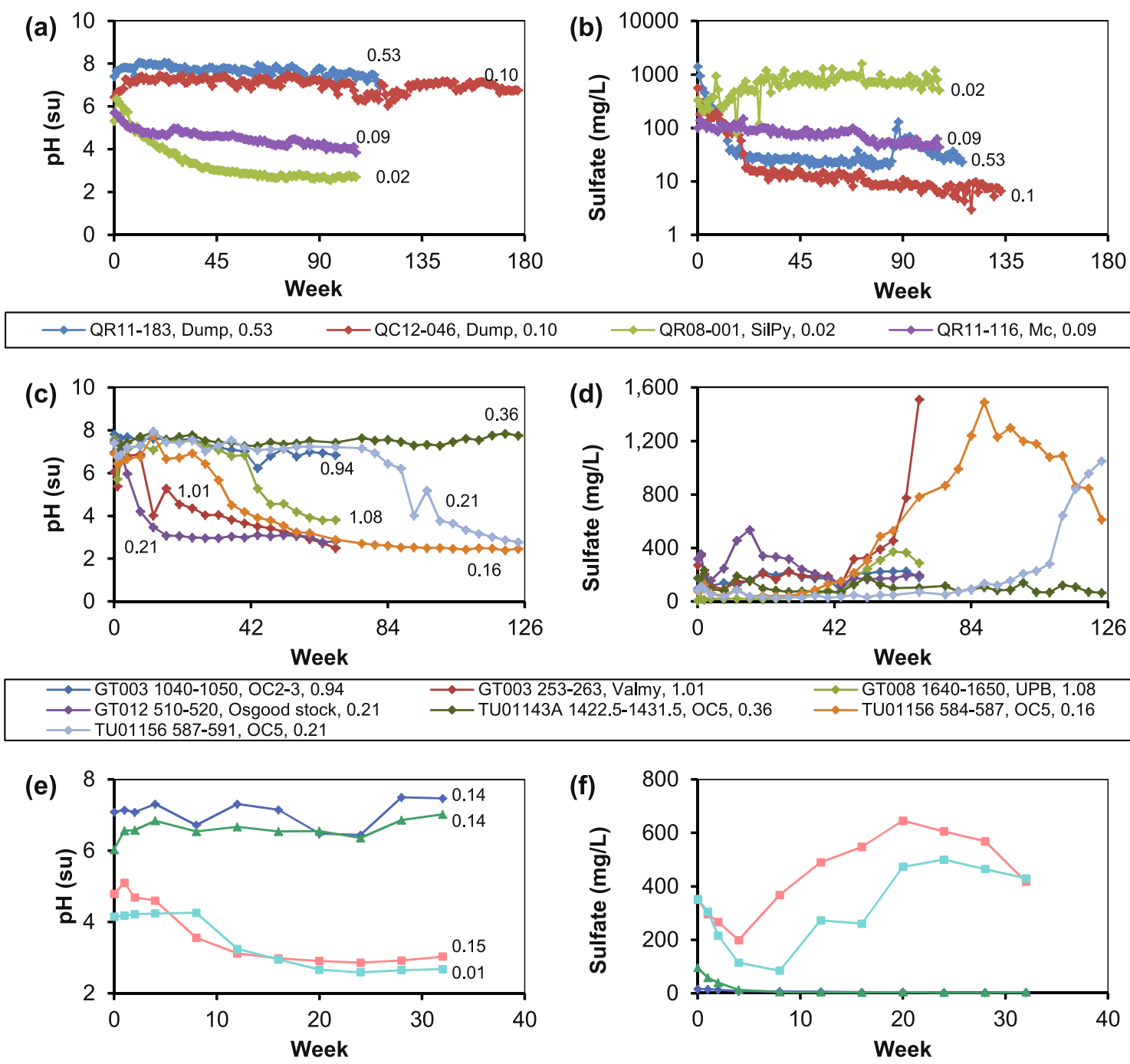

—GSPX-783 Pp-bh-Lch Cap I —-GSPX-785 Pp-bh-P_Leach A — GSPX-793 Pp-qsp-Lch Cap I —-GSPX-795 Drill PP-bh-Hypo A
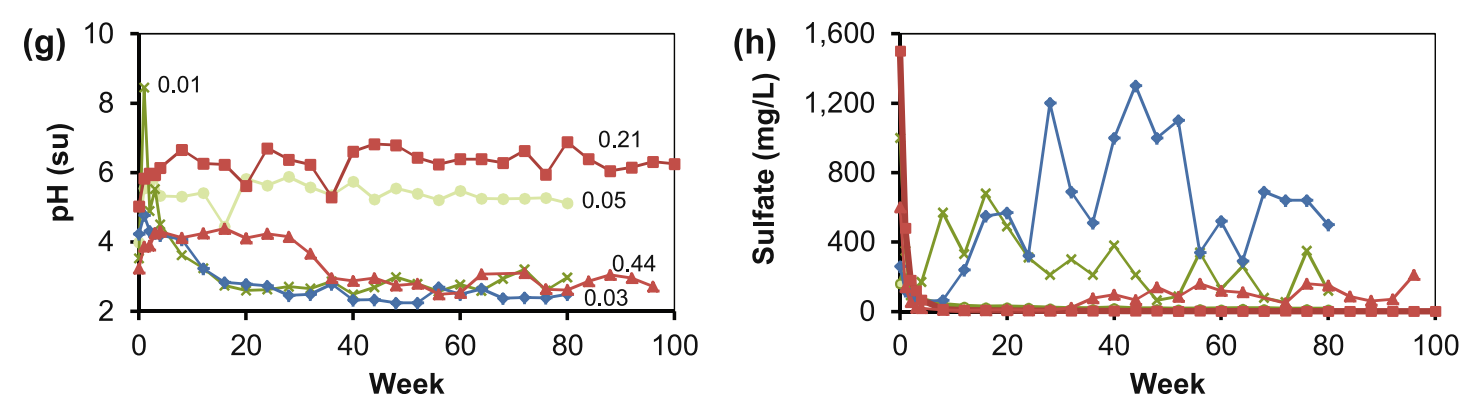

$\mathrm{Ar}$ - Oxide (Cell 2) $\quad$ — Ar - Non-Oxide (Cell 4) $\longrightarrow \mathrm{Si}$ - Non-Oxide (Cell 11) $-\mathrm{AL}-\mathrm{Oxide}(\mathrm{Q} 3) \quad \longrightarrow \mathrm{AL}-\mathrm{Oxide}(\mathrm{Q} 4)$

Fig. 8 a pH and $\mathbf{b ~ S O} 4$ in 4 Robinson HCTs, $\mathbf{c}$ pH and $\mathbf{d ~ S O}$ in 7 TR HCTs, e pH and $\mathbf{f} \mathrm{SO}_{4}$ in 4 Mine $\mathrm{C}$ HCTs, $\mathbf{g}$ pH and $\mathbf{h} \mathrm{SO}_{4}$ in $5 \mathrm{Hycroft}$ HCTs. The ABA ratio for each HCT is identified on $\mathbf{a}, \mathbf{b}, \mathbf{c}, \mathbf{e}$, and $\mathbf{g}$ 
hundred HCTs, there were instances where a single week of data exhibited a $\mathrm{pH}$ that was inconsistent with the prior and following weeks (Fig. 7). Therefore, the second-lowest HCT leachate $\mathrm{pH}$ was used to avoid misinterpretation unless there was an obvious additional outlier, e.g. TU01507 460-477 (Fig. 7a).

\section{Robinson}

Some HCTs, especially weathered dump materials, exhibit initial flushing of solutes that had accumulated on the samples prior to HCT analysis, while others demonstrate behavior consistent with sulfide mineral oxidation (Fig. 8). Four of the cells (QR11-183 50-70, ABA =0.53; QC 12-046 107-127, ABA =0.10; QR11-116 40-60, $\mathrm{ABA}=0.09$; and QR08-001 515-535, ABA = 0.02) show some interesting features. First, leachate acidification generally proceeds according to the ABA ratio, with the lowest generating the lowest $\mathrm{pH}$ (Fig. 8a), while $\mathrm{SO}_{4}$ production (Fig. 8b) also appears related to the ABA ratio, except that the 0.1 and $0.53 \mathrm{ABA}$ ratio samples are transposed. However, QR11-183 50-70 and QC 12-046 107-127, both with ABA ratios < 1.2, failed to generate acid through 116 and 177 weeks, respectively.

(a)
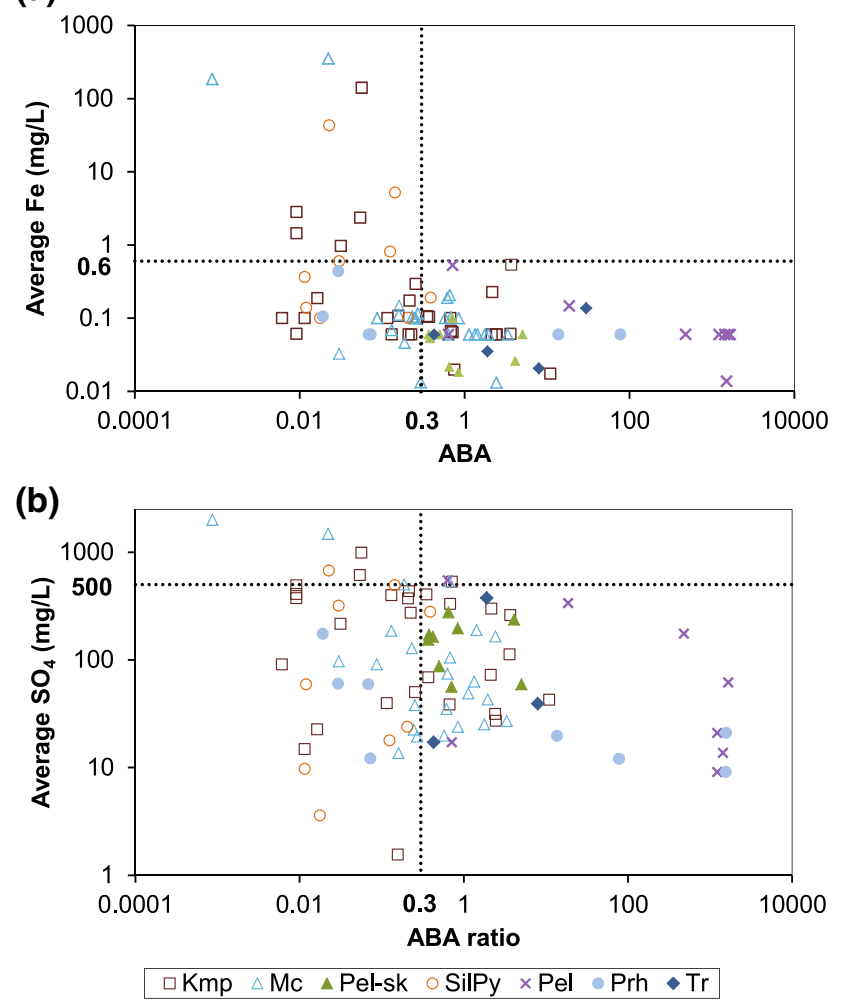

Fig. 9 Average $\mathrm{Fe}$ (a) and $\mathrm{SO}_{4}$ (b) in Robinson HCT leachate as a function of the ABA ratio
Sulfate is a good example of a conservative indicator of weathering reactions, accounting for either dissolution of acid sulfate minerals (e.g. jarosite) at the start of a HCT (Maest and Nordstrom 2018), or generated as sulfide minerals oxidize later in the test, while iron is a co-product of pyrite, chalcopyrite, marcasite, and pyrrhotite oxidation. Both were measured with greater frequency (weekly) than other solutes (run by ICP on the $0,1,2,4,8,12,16,20$, and later pore volume leachates, as required).

Materials with an ABA ratio $>0.3$ did not generate $\mathrm{Fe}>0.6 \mathrm{mg} / \mathrm{L}$ (the US drinking water and NDEP Profile I standard). When the ABA ratio was $<0.3$, less than half the samples exhibited $\mathrm{Fe}>0.6 \mathrm{mg} / \mathrm{L}$ (Fig. 9a), with 74 of the 86 samples exhibiting average $\mathrm{Fe}<0.6 \mathrm{mg} / \mathrm{L}$. For the lithologyspecific samples, 80 of 86 HCTs with an ABA ratio $>0.3$ generated $<500 \mathrm{mg} / \mathrm{L} \mathrm{SO}_{4}$ (the US secondary drinking water and NDEP Profile I standard). The remaining 5 HCTs (with an $\mathrm{ABA}$ ratio $>0.3$ ) exhibited an average $\mathrm{SO}_{4}>500 \mathrm{mg} / \mathrm{L}$ (Fig. 9b). Consequently, an ABA ratio cutoff of 0.3 results in few $\mathrm{Fe}$ and/or $\mathrm{SO}_{4}$ exceedances of numerical standards.

\section{Turquoise Ridge}

Contrary to the predictable patterns of solute generation in Robinson HCTs, the TR HCTs had more anomalous $\mathrm{pH}$
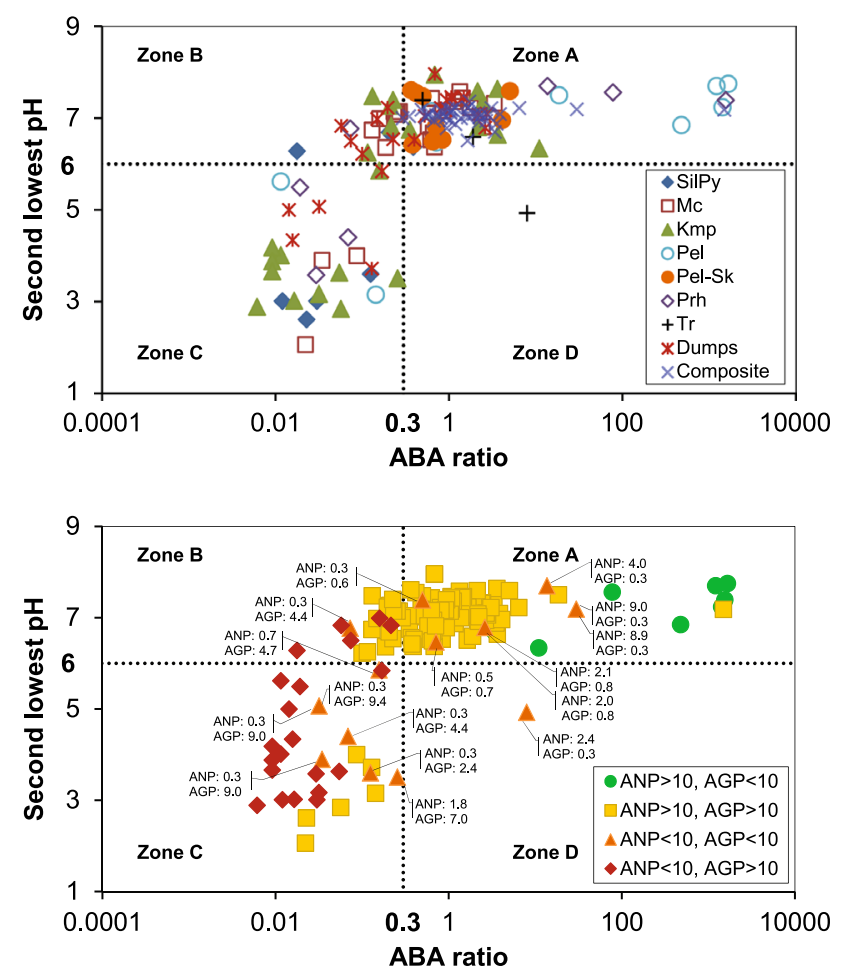

Fig. 10 a 150 HCTs from different lithologies at Robinson demonstrating a lack of acid generation above a $0.3 \mathrm{ABA}$ ratio cutoff that is independent of lithology or pit, and $\mathbf{b}$ classification of HCTs by ANP and AGP 
trends with respect to the $\mathrm{ABA}$ ratio (Fig. 8c). Also distinct from Robinson, there was a muted initial $\mathrm{SO}_{4}$ pulse; instead $\mathrm{SO}_{4}$ generation resulted from sulfide oxidation, e.g. in TUO1156 584-587 between weeks 44-126, GT003 253-263 from week 40, and in TUO1156 587-591 after week 100, as the $\mathrm{pH}$ decreased below 4 (Fig. 8d).

\section{Mine C}

Two of the samples that generated acidic leachate (785 and 795) had an AGP of 34 and $46 \mathrm{t}$ of $\mathrm{CaCO}_{3} / \mathrm{Kt}$ of waste rock, and an ANP of 5 and $<0.3 \mathrm{t}$ of $\mathrm{CaCO}_{3} / \mathrm{Kt}$ of waste rock, respectively (Supplemental Table 3). Consequently, there was insufficient buffering capacity to prevent the onset of acidification. In contrast, samples 783 and 793, both with an ANP of $2.1 \mathrm{t}$ of $\mathrm{CaCO}_{3} / \mathrm{Kt}$ of waste rock and ANP $<0.3$ $\mathrm{t}$ of $\mathrm{CaCO}_{3} / \mathrm{Kt}$ of waste rock (Supplemental Table 3) were functionally inert, so the effluent remained $\mathrm{pH}$ circumneutral after 32 weeks (Fig. 8e). Regardless, from a practical perspective, both would be identified as PAG because of their ABA ratio of 0.14 , which would qualify them for a PAG cell.

\section{Hycroft}

Select HCTs are characteristic of the entire data set, in that, an acid-generating pattern, when it occurred, was established early (typically within 20 weeks, Fig. $8 \mathrm{~g}$ ). After an initial flush, $\mathrm{SO}_{4}$ increased in cell 11 (Fig. 8h) as it transitioned to sulfide oxidation in week 12 as the $\mathrm{pH}$ decreased below 4 (Fig. 8g). In the case of cell Q4 (ABA =0.44), AGP and ANP were both low, 1.5 and $3 \mathrm{t}$ of $\mathrm{CaCO}_{3} / \mathrm{Kt}$ of waste rock, respectively, so that although the cell became acidic, $\mathrm{SO}_{4}$ production was low because the material is generally inert.

\section{Marigold}

The 31 humidity cells were run for 20-60 weeks, with three cells terminated after 20 weeks, and the remainder running for at least 28 weeks ( 2 cells ran for 60 weeks). The 31 HCTs were all non-PAG with only one exhibiting a decreasing $\mathrm{pH}$ (7.2-5.9 over 60 weeks). Furthermore, only one exhibited a $\mathrm{pH}<5$ (4.9), increasing from that $\mathrm{pH}$ in week 0 to $\mathrm{pH} 6.75$ in week 1 , and maintaining a $\mathrm{pH}$ circumneutral leachate for the ensuing 32 weeks. Both samples were from the reduced Valmy formation (which will account for $<0.1 \%$ of the waste rock). These samples represent a worst-case scenario because they are (a)

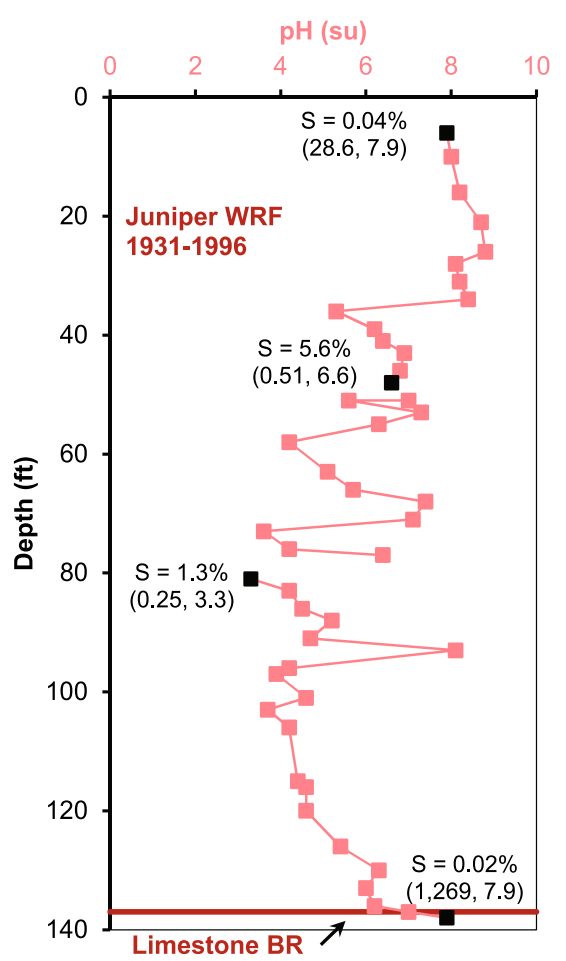

(b)

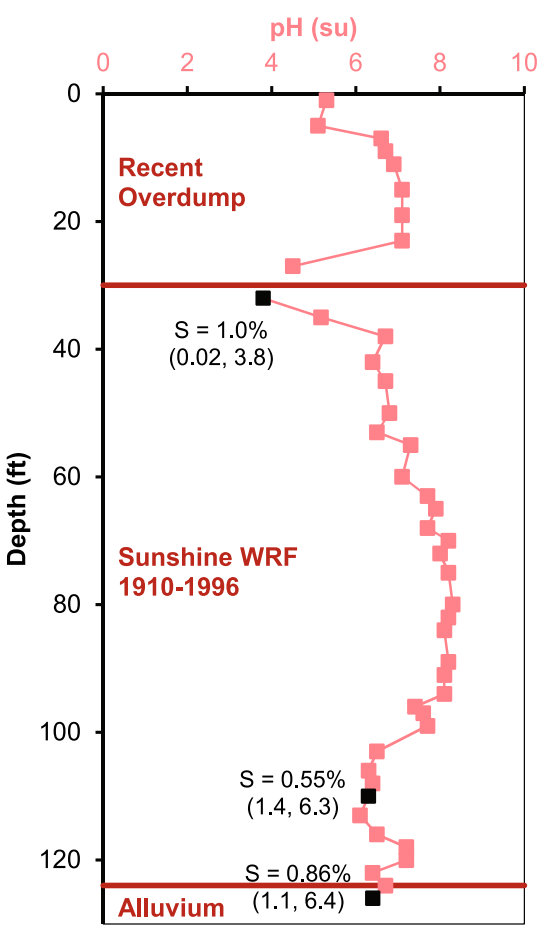

(c)

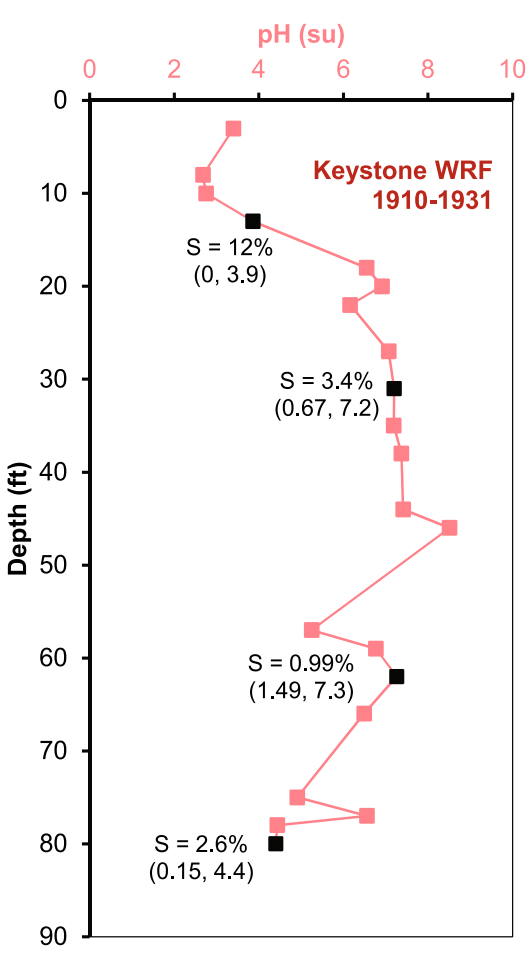

Fig. 11 pH profiles from bores: a B-10, b B-11, and c B-14 (see Fig. 1 for locations); also showing the \% sulfide, ABA ratios, and paste pH. The years of operation are appended for each dump 
Fig. 12 Waste rock bore samples demonstrating an equivalent lack of acid generation above a 0.3 ABA cutoff ratio as the HCT population in Fig. 10

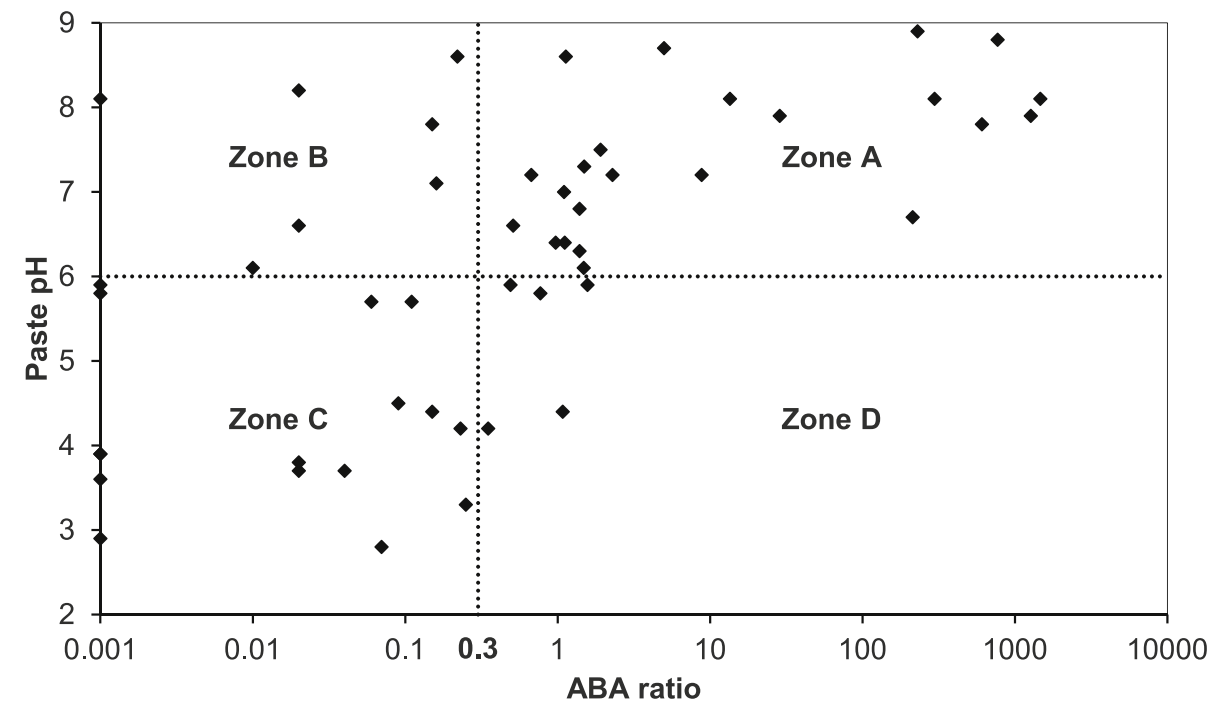

(a)

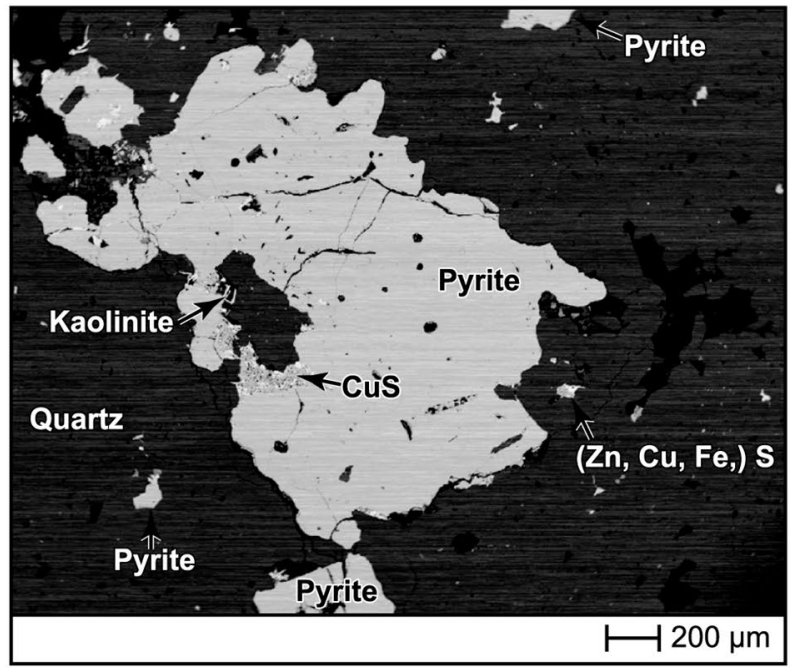

(b)

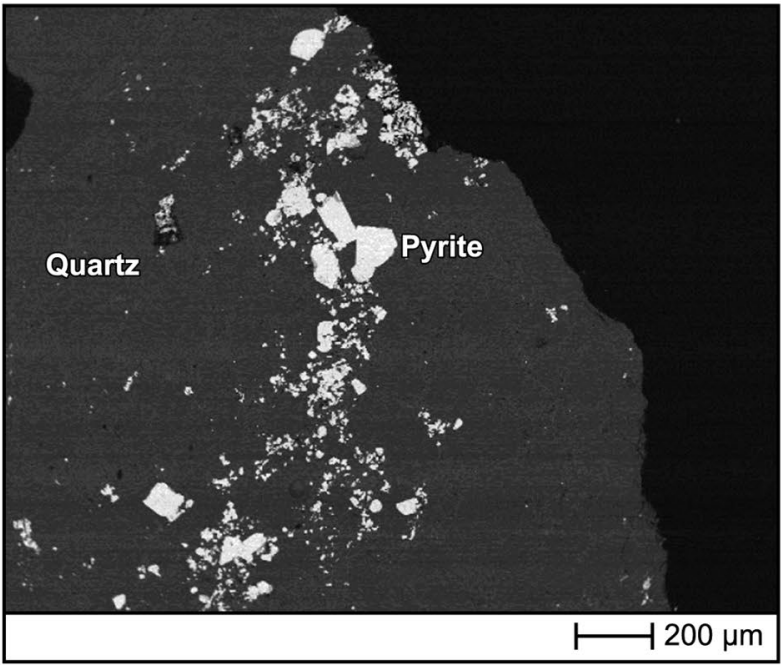

(c)

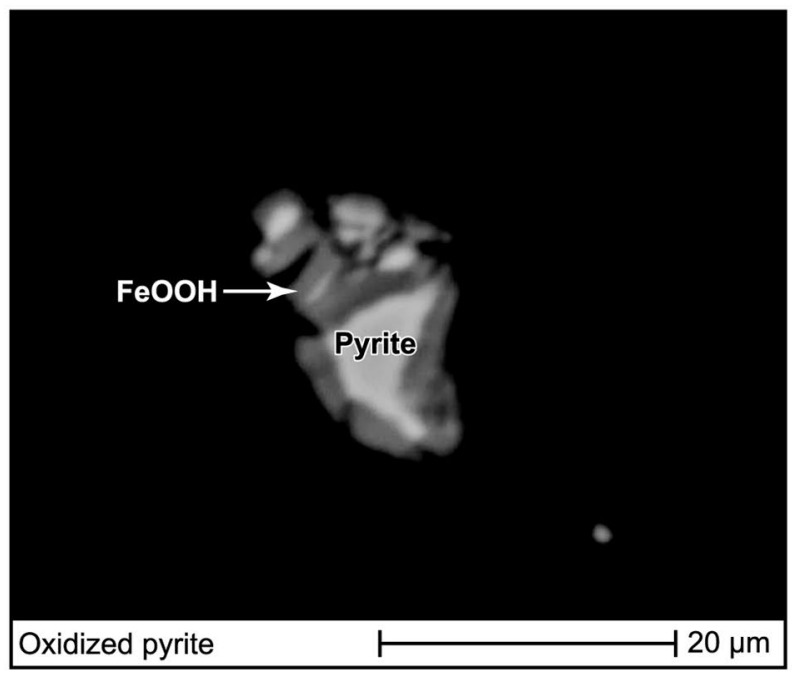

(d)

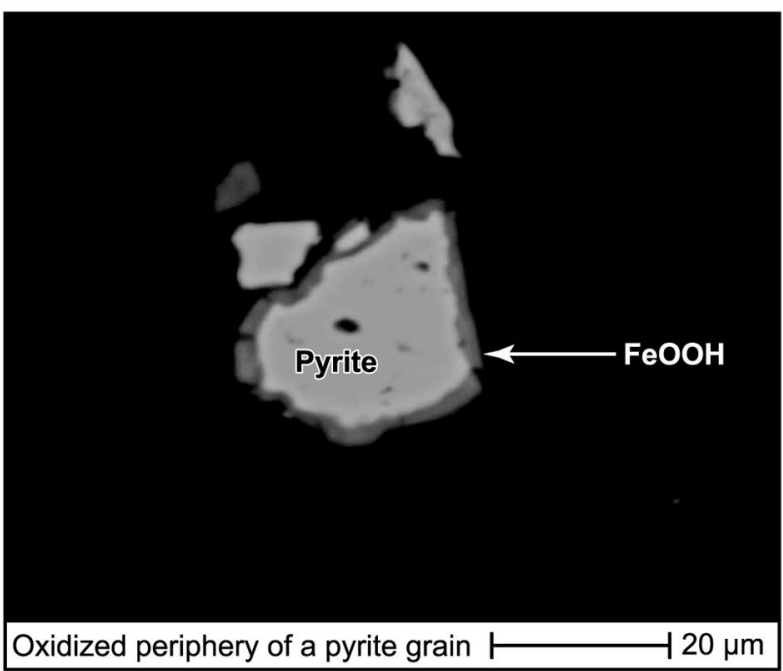

Fig. 13 a, b Electron microprobe images of pyrite and covellite grains encapsulated in quartz, c, $\mathbf{d}$ oxidized "micro-pyrite" particles with a rind of amorphous ferric hydroxide 
approximately 43 and $85 \mathrm{~m}$ below the proposed waste rock envelope (Fig. 2a). The ABA ratios of these two HCTs were $\mathrm{ANP} / \mathrm{AGP}=5 / 29(0.17)$ and 15/31 (0.5) respectively, the two lowest of all the HCT samples.

In addition to the HCTs, paste $\mathrm{pH}$ data were available for 578 samples from reverse circulation drill cores that had been stored outside prior to analysis, allowing a comparison with the $\mathrm{pH}$ of the HCT leachate. The paste $\mathrm{pH}$ ranged from 6 to 10 (Supplemental Table 6), also demonstrating a consistent non-acid generating behavior, despite six samples ( $0.1 \%$ of the population) having an $\mathrm{ABA}$ ratio $<0.1 \%$.

\section{Discussion}

317 HCTs representing a wide cross-section of different lithologies and geographic distributions were analyzed from five different mines. For three mines, the ABA ratio provided a consistent predictor of ARD generation (reproducible leachate $\mathrm{pH}<6$ ), although the ABA ratio cutoff based on this approach varied from mine to mine. At the other two, the narrow ABA ratio distribution precluded establishment of a PAG/non-PAG cutoff ratio. The commonality in our findings is that the ABA ratio appears to provide a site-specific indicator of the ARD potential that is independent of geology or geography.

\section{Robinson Mine}

The 86 HCTs representing the major waste rock lithologies demonstrate a consistent pattern of potential acid generation (defined here as the second lowest $\mathrm{pH}<6$ ) only at an ABA ratio $<0.3$, consistent with the behavior of the 41 composites and the 23 dump samples (Fig. 10a). The $\mathrm{pH}$ cutoff was defined here as that $\mathrm{pH}$ that will not result in
sub-pH 6 leachate. The reason for this pattern is the wide range of ANP (0.3-662 $\mathrm{t}$ of $\mathrm{CaCO}_{3} / \mathrm{Kt}$ of waste rock) and AGP (0.3-495 $\mathrm{t}$ of $\mathrm{CaCO}_{3} / \mathrm{Kt}$ of waste rock) in the deposit.

Of the 150 HCTs run on Robinson materials, 100 had $\mathrm{ABA}$ ratios $>0.3$. Only one sample with an ANP/AGP $>0.3$ (measured using the NCV method) produced a leachate with a pH $<6.0$, while all of the other HCTs with ABA ratios $>0.3$ had no more than 1 leachate with $\mathrm{pH}<6.0$ (Fig. 10b, zone A). The HCT effluent $\mathrm{pH}$ appears not to be a function of the sample lithology or geography (i.e. was not pit-specific). Despite the 0.3 cutoff, 22 samples (Fig. 10b, zone B) below $0.3(44 \%)$ failed to generate acidity $(\mathrm{pH}<6)$.

Of the 86 lithology-specific HCTs, 61 had an ANP/ AGP $<1.2$, yet only 23 generated acid $(\mathrm{pH}<6)$. Of the 64 composite and dump samples, 39 had an ABA ratio $<1.2$, yet only five of these generated leachates with $\mathrm{pH}<6$. The HCT $\mathrm{pH} / \mathrm{ABA}$ ratio distribution was compared with 51 samples from waste rock bores drilled across the site in 1997 that were analyzed for ANP, AGP, and paste pH at different depth intervals (Fig. 11). The waste rock dumps were built beginning in 1910 (Fig. 1), so at depth have been exposed to weathering at the base of the Juniper (B-10), Puritan (B-11), and Keystone (B-14) dumps for over 80 years. The waste rock bore distribution is in general agreement with the HCT data, with only one sample deviating substantially from the $0.3 \mathrm{ABA}$ ratio cutoff (Fig. 12), showing that HCTs provide an insight to longterm waste rock dump reactivity.

The discrepancy between the anticipated and measured HCT leachate chemistry may be due to surface passivation, inclusion of pyrite and other sulfides in inert minerals (Link et al. 1994), or remnant ANP. Robinson mineralogy demonstrates that pyrite may be encapsulated either by co-deposited quartz or calcite (e.g. pre-run HCT samples; Fig. 13a, b) or by reaction byproducts (Figs. 13c, d), possibly explaining
Fig. 14 TRJV pH vs. ABA ratio for underground waste rock demonstrating a cutoff ABA ratio of $0.5(n=49)$. HCT postmortem mineralogy (Fig. 15) is discussed for four of the samples (A through D)

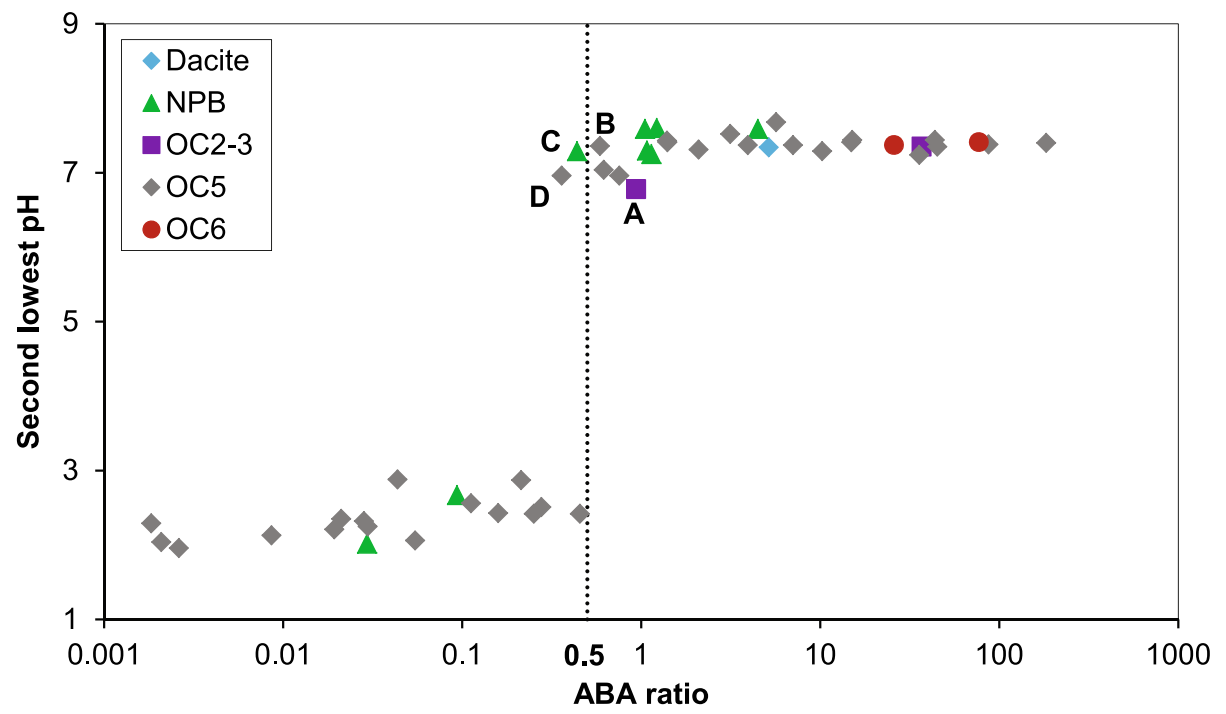


the lack of pyrite reactivity. Parbhakar-Fox et al. (2013) found that secondary HFO formed rims around pyrite and in fractures, while quartz was relatively inert (Dold 2017), i.e. $10.8 \mathrm{mg} / \mathrm{L}$ at $25^{\circ} \mathrm{C}$ (Rimstidt 1997), and so will retain its structural stability, precluding access of water and $\mathrm{O}_{2}$ to pyrite incarcerated in its matrix.

The presence of carbonate-derived alkalinity can also modify pyrite reactivity, resulting in a thin rind of amorphous iron oxide that passivates the mineral surface (Evangelou and Zhang 1995; Parbhakar-Fox et al. 2013). This phenomenon was ubiquitous on both large $(200 \mu \mathrm{m})$ and $10 \mu \mathrm{m}$ diameter "micro-pyrite" particles (Fig. 13c, d). Passivation of the pyrite surface may be described by the reaction:

(a)

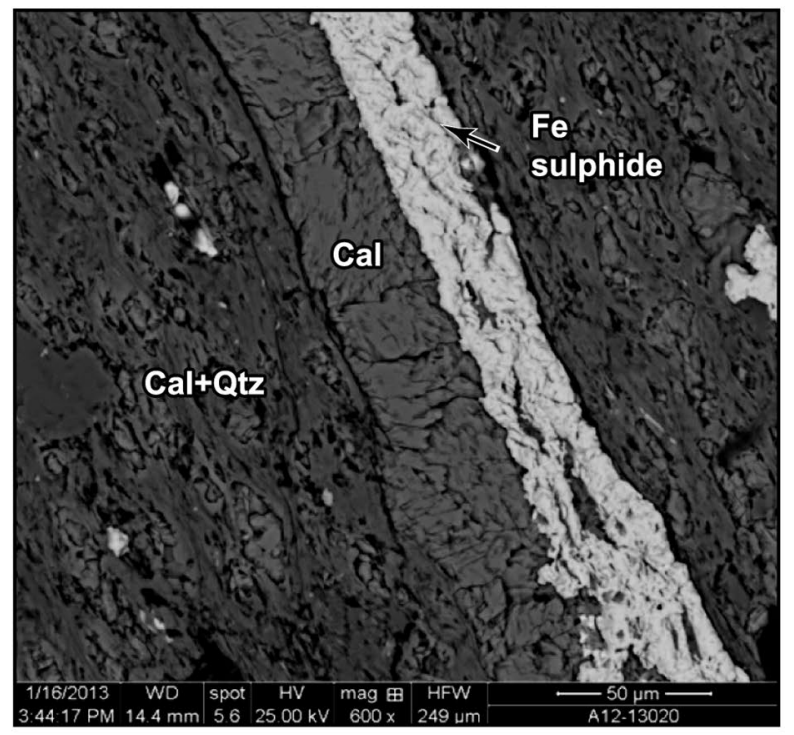

(c)

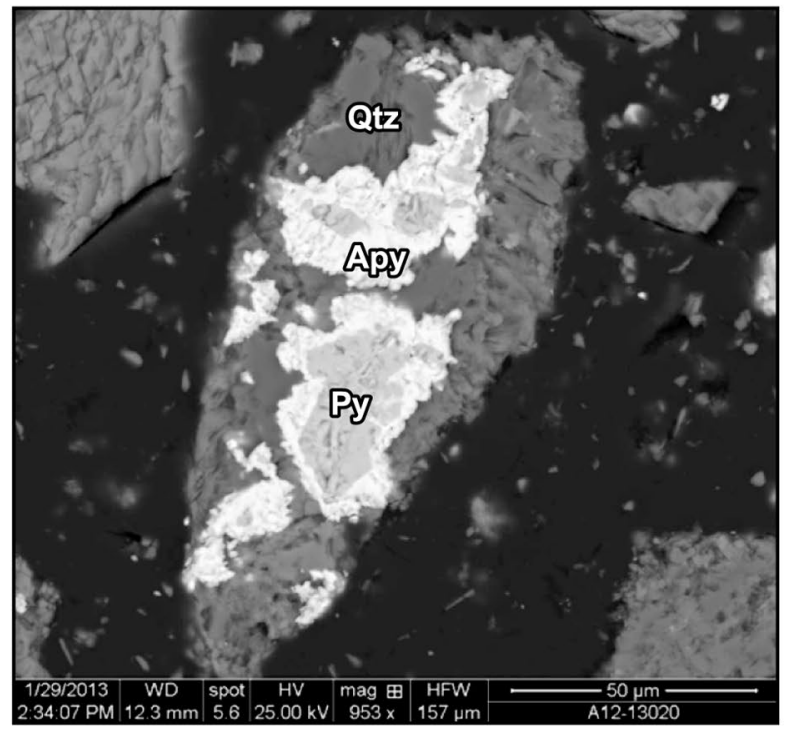

Fig. 15 BSE images of TR HCT samples, a GT003 1040-1050 with a sulfide vein in calcite (cal), b TU01143A 1422.5-1431.5, with realgar (Rlg) and Fe-sulfide encapsulated in quartz, c TU01322 569-578,

$$
\begin{aligned}
& \mathrm{FeS}_{2}+4 \mathrm{CaCO}_{3}+2 \mathrm{H}_{2} \mathrm{O}+4.5 \mathrm{O}_{2} \\
& \quad \rightarrow \mathrm{Fe}(\mathrm{OH})_{3}+2 \mathrm{SO}_{4}^{2-}+4 \mathrm{HCO}_{3}^{-}+4 \mathrm{Ca}^{2+}
\end{aligned}
$$

While the reported $\mathrm{ABA}$ ratio accounts for the consumption of four moles of calcite by each mole of pyrite, if the surface is passivated, only the surficial pyrite is reactive, so less carbonate may be required to passivate the pyrite surface than based purely on stoichiometric considerations.

Typically, where not massive, carbonate occurs as postmineralization coatings and fracture fill, rather than as inclusions inside quartz or pyrite. Conversely, pyrite can be hosted

(b)

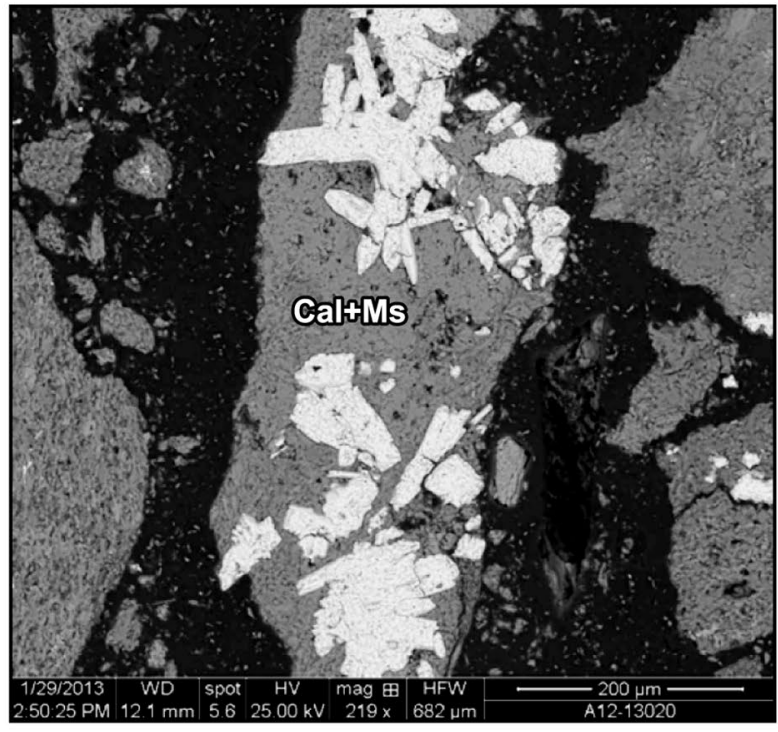

(d)

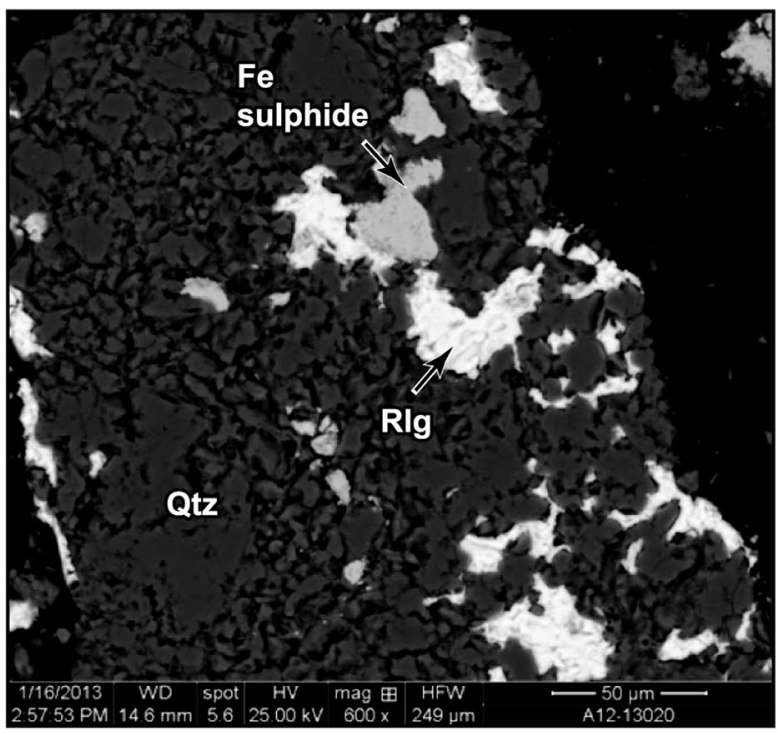

arsenopyrite (Apy) and pyrite (Py) hosted in quartz, and d TU01184 181-189, with pyrite exposure limited by encapsulation within calcite (Cal) and muscovite (Ms) 
in massive quartz and limestone; hence, the sulfide and carbonate reaction morphologies are not equivalent.

\section{TR}

At TR, the 49 HCTs, in or within $3 \mathrm{~m}$ of the underground mine waste rock envelope, exhibit an ABA ratio cutoff of 0.55 (Fig. 14). This is the only mine where there was a relatively small proportion $(\approx 5 \%)$ of the sub-ABA ratio cut off HCTs that did not generate acidity.

Samples A and B (Fig. 14) with ABA ratios of 0.94 and 0.59 had a second highest HCT pH of 6.8 and 7.6, respectively. In sample A, Fe sulfide was veined in a calcite host (Fig. 15a), so presumably pyrite was less available for oxidation, while in B (Fig. 15b), sulfide was predominantly included in calcite (Cal) and muscovite (Ms). Samples C and D were both below the ABA PAG cut-off ratio (0.36 and 0.44 ), yet were anomalously alkaline, with the second most acidic leachates of $\mathrm{pH} 7.27$ and 7.0, respectively (Fig. 14). Both samples contained sulfide incarcerated in quartz (Figs. 15c, d), presumably inhibiting sulfide reactivity and explaining the elevated leachate $\mathrm{pH}$.

\section{Mine C}

Based on the 61 HCTs, an ABA ratio of 1.6 differentiates PAG from non-PAG material (Fig. 16). This data set is important because it demonstrates that it would be inappropriate to generalize PAG/non-PAG cutoffs without an adequate body of test information from a specific mine, and that empirical analysis of waste rock lithologies should be an essential element of any PAG waste rock reclassification exercise. Despite the 1.6 ABA ratio cutoff, 16 cells (26\%) with $\mathrm{ABA}$ ratios below this value failed to generate acidity (i.e. a second lowest $\mathrm{pH}<6$ ).
While four cells $(783,785,793$, and 795) leached some $\mathrm{SO}_{4}$ from salt dissolution prior to week 4, subsequent $\mathrm{SO}_{4}$ production was indicative of sulfide oxidation (Fig. 8f). The leachate chemistries were consistent with the sample mineralogy, with cells 785 and 795 having $2 \%$ and $4 \%$ pyrite, respectively, while cells 783 and 793 contained $0.02 \%$ and $0.11 \%$, respectively (Table 2). Cells 785 and 795 also contained $0.26 \%$ and $0.08 \%$ pyrrhotite, arsenopyrite, and chalcopyrite, which were not detected in 783 and 793 (Table 2).

\section{Hycroft}

Only two of the 26 HCTs had an ABA ratio $>0.3$ while 22 had an ABA ratio <0.1 (Fig. 17). All the silicic and all but one of the argillic HCTs generated a second lowest $\mathrm{pH}<6$, while four out of the eight acid leach materials generated a $\mathrm{pH}>6$.

The ANP distribution was typically $<3 \mathrm{t}$ of $\mathrm{CaCO}_{3} / \mathrm{Kt}$ of waste rock, while the AGP ranged from 3-147 $\mathrm{t}$ of $\mathrm{CaCO}_{3} /$ $\mathrm{Kt}$ of waste rock, with an average of $44 \mathrm{t}$ of $\mathrm{CaCO}_{3} / \mathrm{Kt}$ of waste rock (Supplemental Table 4). In contrast to Robinson, Mine C, and TRJV, the absence of higher ANP at Hycroft produced ABA ratios that were mosttly $<0.1$ (Fig. 17); consequently, defining an $\mathrm{ABA}$ ratio cutoff at Hycroft is not meaningful. However, 6 out of the 26 HCTs (23\%) failed to generate a $\mathrm{pH}<6$ leachate even at low ABA ratios (Fig. 16). No HCT mineralogy was available for this site.

\section{Marigold}

It is also not possible to define an ABA ratio cutoff for Marigold, but for a different reason than at Hycroft. Marigold is hosted in an oxide deposit where mining has been on-going for over 30 years, during which time there has never been any acid seeps, and the mine has always mined oxide rock (above
Fig. 16 Mine $\mathrm{C}$ second lowest $\mathrm{pH}$ vs. ABA ratio demonstrating an ABA ratio cutoff at 1.6 $(n=63)$

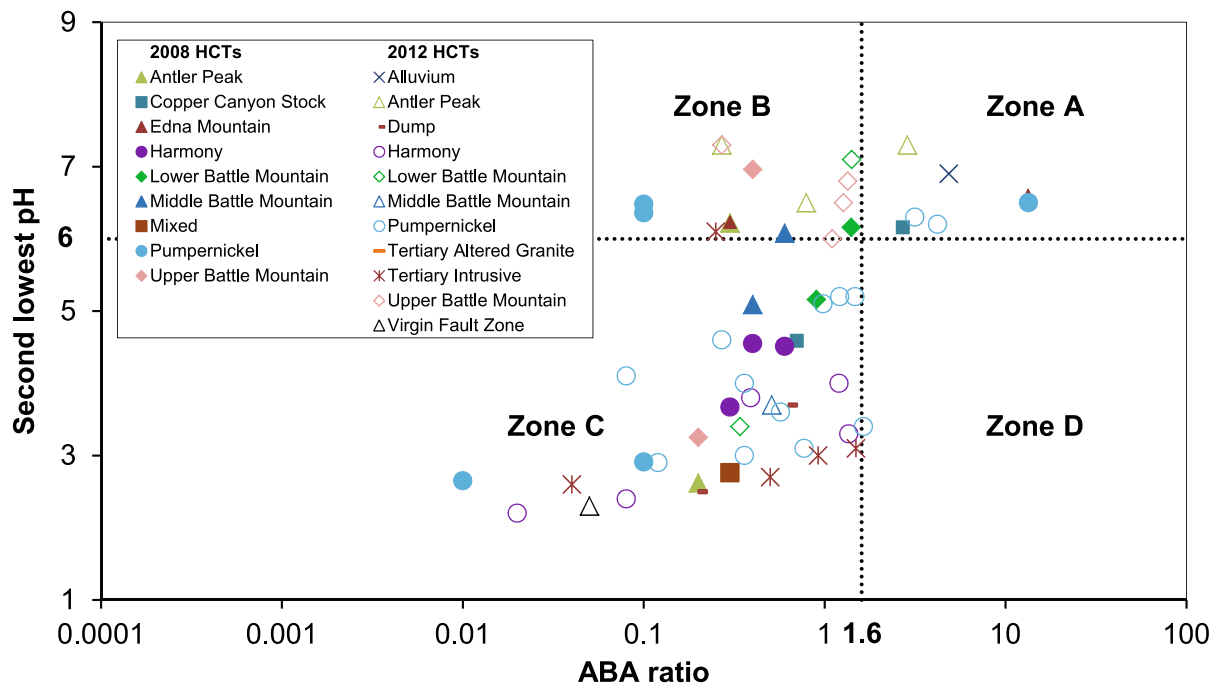


Table 2 Mineralogy of Mine C waste rock

\begin{tabular}{|c|c|c|c|c|c|c|c|c|}
\hline \multirow{3}{*}{$\begin{array}{l}\text { Sample ID } \\
\text { Formation } \\
\text { Mineral }\end{array}$} & \multirow{2}{*}{\multicolumn{2}{|c|}{$\frac{\text { GSPX-783 }}{\text { Pumpernickel }}$}} & \multirow{2}{*}{\multicolumn{2}{|c|}{$\frac{\text { GSPX-785 }}{\text { Pumpernickel }}$}} & \multirow{2}{*}{\multicolumn{2}{|c|}{$\frac{\text { GSPX-793 }}{\text { Pumpernickel }}$}} & \multirow{2}{*}{\multicolumn{2}{|c|}{$\frac{\text { GSPX-795 Drill }}{\text { Pumpernickel }}$}} \\
\hline & & & & & & & & \\
\hline & MLA & XRD & MLA & XRD & MLA & XRD & MLA & $\mathrm{XRD}$ \\
\hline Ankerite & 0.01 & & & & & & & \\
\hline Amphibole & 1.42 & 3 & 0.35 & 1 & 0.19 & & 3.41 & 5 \\
\hline Andradite & 0.04 & & 0.004 & & 0.01 & & 0.01 & \\
\hline Apatite & 0.09 & & 0.04 & & 0.003 & & 0.03 & \\
\hline Arsenopyrite & & & 0.01 & & 0.01 & & 0.01 & \\
\hline Barite & & & 0.004 & & & & & \\
\hline Biotite & 0.94 & & 3.74 & & 0.30 & & 2.75 & \\
\hline Calcite & 0.003 & & 0.003 & & & & & \\
\hline Chalcocite & & & & & & & 0.01 & \\
\hline Chalcopyrite & & & 0.004 & & & & 0.02 & \\
\hline Chlorite & 0.71 & 3 & 2.03 & 10 & 0.32 & & 0.17 & \\
\hline Copper & & & 0.01 & & & & & \\
\hline Covellite & & & & & & & 0.005 & \\
\hline Crandallite & & & & & 0.01 & & & \\
\hline Diopside & 1.92 & & 0.58 & & 0.03 & & 3.54 & \\
\hline Epidote & 0.09 & & 0.36 & & & & 0.06 & \\
\hline $\mathrm{FeOx}$ & 0.55 & $<1$ & 0.05 & 3 & 0.25 & & 1.73 & \\
\hline Illite & 3.07 & 3 & 6.89 & 4 & 4.85 & 24 & 2.97 & 5 \\
\hline Iron & 0.01 & & & & 0.02 & & 0.05 & \\
\hline Jarosite & & & 0.01 & & 0.09 & 2 & 0.71 & 6 \\
\hline K-feldspar & 22.10 & 15 & 20.97 & 13 & 6.35 & & 11.20 & 6 \\
\hline Kaolinite & & $1-2 ?$ & & & 0.01 & & 0.002 & 3 \\
\hline Lipscombite & & & & & 0.03 & & & \\
\hline $\mathrm{MnOx}$ & 0.04 & & & & & & & \\
\hline Monazite & & & & & & & 0.005 & \\
\hline Plagioclase & 3.20 & 7 & 4.54 & 5 & 0.49 & & 0.39 & \\
\hline Pyrite & 0.02 & & 2.00 & & 0.11 & & 4.06 & 4 \\
\hline Pyrrhotite & 0.004 & $<1$ & 0.26 & 1 & 0.02 & & 0.08 & \\
\hline Quartz & 64.65 & 67 & 57.82 & 62 & 86.01 & 74 & 63.62 & 72 \\
\hline Rutile & 0.03 & & 0.03 & & 0.04 & & 0.09 & \\
\hline Siderite & 0.17 & & 0.03 & & 0.18 & & 0.75 & \\
\hline Smectite & 0.72 & & 0.08 & & 0.57 & & 4.19 & \\
\hline Sphalerite & & & 0.01 & & 0.004 & & & \\
\hline Sphene & 0.13 & & 0.12 & & & & 0.12 & \\
\hline Talc & & & & & & & 0.003 & \\
\hline Trolleite & & & & & 0.06 & & 0.003 & \\
\hline Zircon & 0.07 & & 0.09 & & 0.04 & & 0.02 & \\
\hline Total & 100.00 & 98 & 100.00 & 99 & 100.00 & 100 & 100.00 & 101 \\
\hline
\end{tabular}

$M L A$ mineral liberation analysis, $X R D \mathrm{X}$-ray diffraction analysis the redox transition zone). Consequently, the HCTs were all non-PAG (Fig. 18), so while the ANP data range from 0.3-230 $\mathrm{t}$ of $\mathrm{CaCO}_{3} / \mathrm{Kt}$ of waste rock, the AGP ranges only from $0.3-42$ $\mathrm{t}$ of $\mathrm{CaCO}_{3} / \mathrm{Kt}$ of waste rock, with an NNP range of $252 \mathrm{t}$ of
$\mathrm{CaCO}_{3} / \mathrm{Kt}$ of waste rock. As a practical matter, definition of an ABA ratio cutoff at Marigold is unnecessary because all the waste rock is oxide, so that there are no geochemical constraints on its disposition. Comparing the 578 paste $\mathrm{pH}$ data from the same lithologies as the 31 HCTs (Fig. 18) shows that the paste $\mathrm{pH}$ data are generally consistent with the HCT leachate. 
Fig. 17 The relationship between HCT $\mathrm{pH}$ and ABA ratio at the Hycroft mine. The absence of a higher ANP population renders an ABA cutoff $\operatorname{moot}(n=28)$

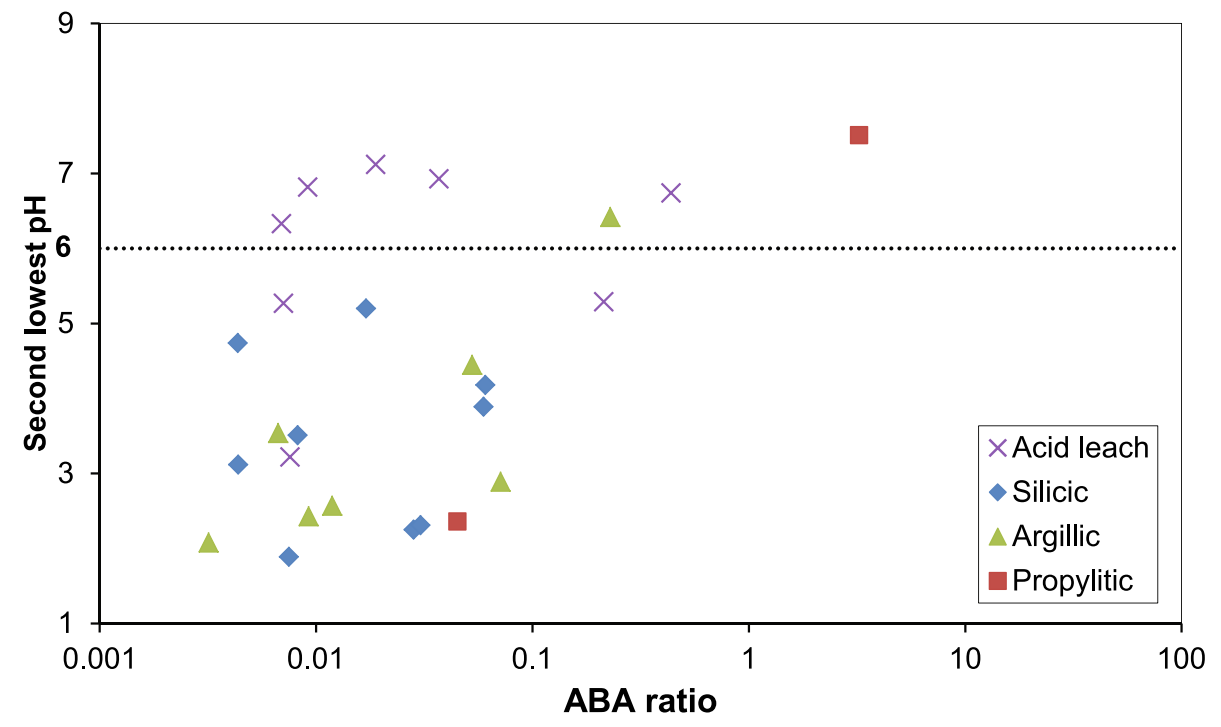

Fig. 18 Relationship between the $\mathrm{ABA}$ ratio and 578 paste $\mathrm{pH}$ analyses (open symbols) and second lowest HCT leachate $\mathrm{pH}$ (solid symbols) for Marigold waste rock. The absence of a substantial acid-generating population renders an $\mathrm{ABA}$ ratio cutoff moot

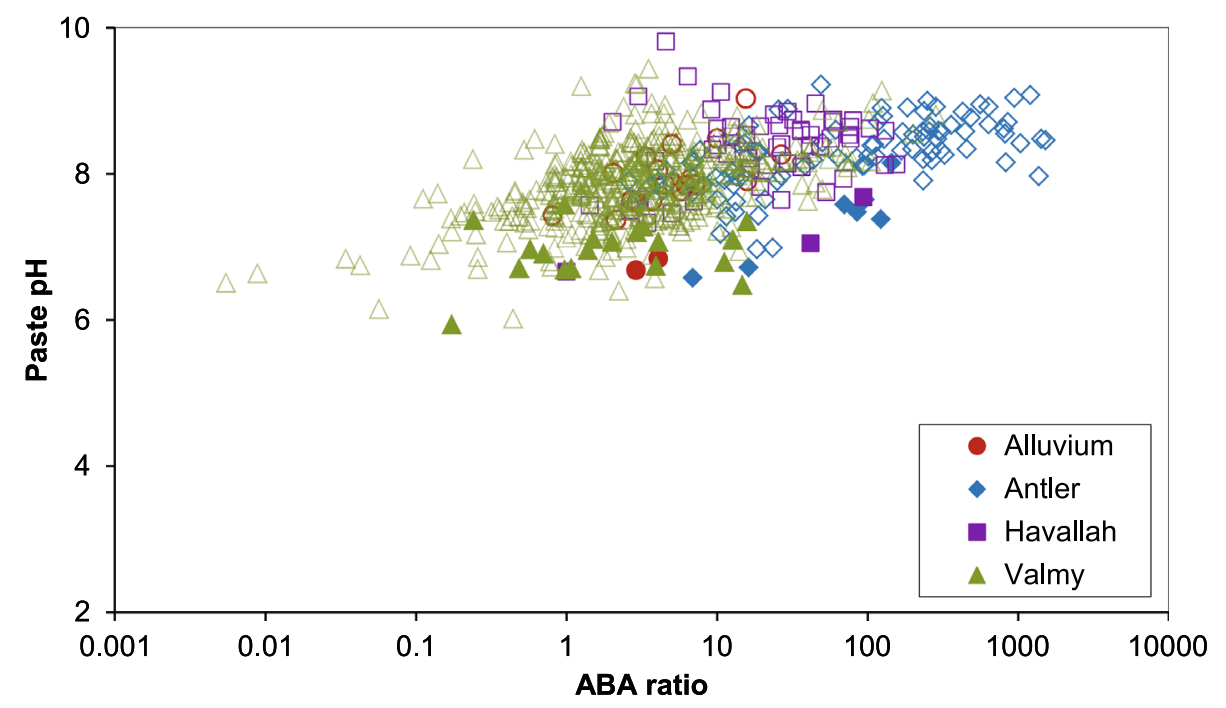

\section{Conclusions}

Although Erguler et al. (2014), Erguler and Erguler (2017) identified column dimensions and particle size as confounding factors when interpreting HCT results, all of the tests described in this paper used similar dimension equipment and standard protocols. Of the 317 HCTs in this paper, 213 remained above $\mathrm{pH} 6$. Of the 104 generating sub-pH 6 conditions, two had a $\mathrm{pH}<2$ (with the lowest $\mathrm{pH}$ being 1.89), 40 had a pH between $2-3,31$ between 3-4, 16 between $4-5$, and 15 between 5-6, so if the HCT charge had a proclivity to acid generation, it succeeded. In addition, if an HCT tended to acid generation, it typically did so within 50 weeks. As a practical matter, if the $\mathrm{pH}$ starts to decrease, or $\mathrm{Fe}$ or $\mathrm{SO}_{4}$ increase, the general practice is to continue running the HCT. Consequently, the method does not seem to influence the outcome.

Neither does pre-exposure of material to the environment appear to accelerate HCT reactivity. At Robinson, 23 run-ofmine dump material HCTs followed the same second lowest $\mathrm{pH}$ vs. ABA ratio trajectory as the samples taken from the core (Fig. 10a). In addition, after decades of weathering, the dump profile samples (Fig. 11) demonstrated a similar $\mathrm{pH} / \mathrm{ABA}$ ratio distribution as the HCTs (Fig. 12), indicating that the cells were run long enough to provide insights into long-term waste rock dump reactivity.

The reason for a quasi-sharp cutoff at three of the mines appears partially related to the NNP range (Table 1) (i.e. $1144 \mathrm{t}$ of $\mathrm{CaCO}_{3} / \mathrm{Kt}$ of waste rock at Robinson, $1268 \mathrm{t}$ of $\mathrm{CaCO}_{3} / \mathrm{Kt}$ of waste rock at TRJV, and $849 \mathrm{t}$ of $\mathrm{CaCO}_{3} / \mathrm{Kt}$ of waste rock at Mine $\mathrm{C}$ ), which span highly acid-generating to highly basic rock. In contrast, the range of NNP at Hycroft 
was $195 \mathrm{t}$ of $\mathrm{CaCO}_{3} / \mathrm{Kt}$ of waste rock (lacking elevated ANP) and $252 \mathrm{t}$ of $\mathrm{CaCO}_{3} / \mathrm{Kt}$ of waste rock at Marigold (lacking AGP).

There are four zones associated with the ABA ratio cutoff. Using Robinson as an example (Fig. 10b), Zone A consists of material with an abundance of neutralizing capacity, primarily due to limestone. Zone B samples failed to generate acid through the course of the HCTs, possibly due to inhibition of sulfide reactivity due to pyrite incarceration, passivation by oxide rinds, or simply because they were not run long enough. In contrast, Zone C samples represent a continuum from abundant sulfide and insufficient carbonate to limited sulfide but no carbonate; neither condition prevents acid production.

There was one cell in Zone D that putatively should not have generated acid. However, the ABA ratio was measured on a split of the HCT material, so this result may be due to an analytical error or the nugget effect. There were no other samples in Zone D, which was likely due to the abundance of limestone, which prevents acid generation above the ABA ratio cutoff. Materials with both limited neutralizing and acid-generating capacity (both ANP and AGP $<10 \mathrm{t}$ of $\mathrm{CaCO}_{3} / \mathrm{Kt}$ of waste rock) represent generally inert waste rock that plot in all four zones (Fig. 10b).

In practice, the important metric is the HCT population, which is used to distinguish behavior patterns, rather than a single HCT. Based on the five populations evaluated in this paper, there are clearly different mechanisms at play controlling acid generation at the different mines. Regulatory agencies are concerned with ensuring that waste rock is placed appropriately. To this end, the samples selected for HCTs (the population) typically err on the side of caution, i.e. are more PAG-like than is truly representative of the waste rock to be mined.

In summary, these data sets demonstrate that a waste rock mine-specific ABA ratio PAG cutoff must be developed on an empirical basis using an adequate number of samples covering the entire $\mathrm{ABA}$ ratio range at the mine, because the ABA ratio cutoff, where one could be established, varied between mines. Nevertheless, this approach still retains a level of conservancy, because for several lithologies, waste rock manifesting PAG ABA ratios (below the cutoff) failed to generate acid in the HCT (e.g. Zone B in Figs. 10 and 12). Regardless, such waste rock would have been routed to a PAG cell because it would have been below the mine-specific ABA ratio cutoff.

The basis for some HCTs not generating the anticipated acidity appears related to the potential for surface passivation, sequestration in inert minerals, or carbonate neutralization. Additional testing of pre-run and post-mortem HCTs across a wide spectrum of lithologies and AGP/
ANPs is clearly important to further substantiate these conclusions.

Acknowledgements The authors are grateful to all the mines for the use of their data. While Geomega has, or has previously had, a commercial relationship with each facility, this paper is an independent research effort for which no remuneration was requested or received. The research did not receive any specific grant from funding agencies in the public, commercial, or not-for-profit sectors. We are also indebted to several anonymous reviewers, whose comments helped refine our thinking, resulting in a stronger, more rigorous manuscript.

Open Access This article is distributed under the terms of the Creative Commons Attribution 4.0 International License (http://creativeco mmons.org/licenses/by/4.0/), which permits unrestricted use, distribution, and reproduction in any medium, provided you give appropriate credit to the original author(s) and the source, provide a link to the Creative Commons license, and indicate if changes were made.

\section{References}

Agricola G (1556) De re Metallica. Translated 1950 by Hoover HC, Hoover LH, Martino fine books, Dover

ASTM (2012) Standard test method for laboratory weathering of soil materials using a humidity cell. Method D5744-12. Annual book of ASTM Standards, American Soc for testing and materials

ASTM (American Soc for Testing and Materials) (2007) Standard test methods for analysis of metal bearing ores and related materials by combustion infrared-absorption spectrometry. Method 1915-07. Annual book of ASTM Standards, American Soc for testing and materials

Berger BR, Taylor BE (1980) Pre-Cenozoic normal faulting in the Osgood Mountains, Humboldt County, Nevada. Geology 12:594-598

Brough CP, Warrender R, Bowell RJ, Barnes A, Parbhakar-Fox A (2013) The process mineralogy of mine wastes. Min Eng 52:125-135

Brough CP, Strongman J, Bowell R, Warrender R, Prestia A, Barnes A, Fletcher J (2017) Automated environmental mineralogy: the use of liberation analysis. Min Eng 107:112-122

Caldeira CL, Criminelli VST, Dias A, Osseo-Asare K (2003) Pyrite oxidation in alkaline solutions: nature of the product layer. Int $\mathrm{J}$ Min Process 72:373-386

Center for Streamside Studies (2000) Environmental impacts of hardrock mining in Eastern Washington. College of Forest Resources and Ocean and Fishery Sciences, Univ of Washington, Washington

Cline J, Muntean J, Longo A, Cassinerio M (2008) Collaborative research on fluid pathways and metal transport in Carlin-type gold deposits: insights from the Getchell deposit, final report for the US Geological Survey 2006 Mineral Resources External Research Program (MRERP)

Davis A, Ruby M, Bergstrom P (1992) The bioavailability of arsenic and lead in soils from the Butte Mining district. Environ Sci Technol 26:461-468

Desborough GA, Briggs PH, Mazza N, Driscoll R (1998) Acid-neutralizing potential of minerals in intrusive rocks of the Boulder batholith in northern Jefferson County, Montana. USGS OpenFile Report 98-364, Denver

Dold B (2017) Acid rock drainage prediction: a critical review. J Geochem Explor 172:120-132

Eary LE (2015) Using oxygen consumption rates as a guide to scale up laboratory kinetic data to field conditions. Proc, 10th Int. Congress 
on Acid Rock Drainage (ICARD)/IMWA, Santiago Chile, https ://www.imwa.info/docs/imwa_2015/IMWA2015_Eary_219.pdf

Ebert SW, Rye RO (1997) Secondary precious metal enrichment by steam-heated fluids in the Crowfoot-Lewis hot spring gold-silver deposit and relation to paleoclimate. Econ Geol 92:578-600

Epa US (1996) Method 3050B: acid digestion of sediments, sludges, and soils, revision 2. US Environmental Protection Agency, Washington

Erguler ZA, Erguler GK (2017) The effect of particle size on acid mine drainage generation: kinetic column tests. Min Eng 76:154-167

Erguler GK, Erguler ZA, Akcakoca H, Ucar A (2014) The effect of column dimensions and particle size on the results of kinetic column test used for acid mine drainage (AMD) prediction. Min Eng $55: 18-29$

Evangelou VP, Zhang YL (1995) A review: pyrite oxidation mechanisms and acid mine drainage prevention. Crit Rev Environ Sci Technol 25:141-199

INAP (2009) Global Acid Rock Drainage Guide (GARD Guide). The International Network for Acid Prevention (INAP), http://www. gardguide.com. Accessed 20 March 2018

Link T, Ruby MV, Davis A, Nicholson A (1994) Soil lead mineralogy by microprobe: an interlaboratory comparison. Environ Sci Technol 28:985-988

Maest AS, Nordstrom DK (2018) A geochemical examination of humidity cell tests. Appl Geochem 81:109-131

MEND (2009) Prediction manual for drainage chemistry from suphidic geologic materials. Report 1.20.1. CANMET Mining and mineral sciences laboratories, Smithers, British Columbia

Morin KA, Hutt NM (1998) Kinetic tests and risk assessment for ARD. 5th Annual BC Metal Leaching and ARD Workshop, December 9-10, 1998, Vancouver

NDEP (2014) Bureau of mining regulation and reclamation. Waste rock overburden and ore evaluation guidance document. Carson City, NV, 2014-02-28

NDEP (2015a) Nevada Division of environmental protection. Memo to Robinson Nevada Mining Company. Approval of two EDCs. Carson City, NV, 2015-04-03

NDEP (2015b) Nevada Division of environmental protection. Memo to Nevada mining approved laboratories. 2015 Update to the Nevada Modified Sobek Procedure. Carson City, NV, 2015-02-17
Oraee K, Goodarzi A (2007) A general approach to distribute waste rocks between dump sites in open cast mines. Proc 16th Int Symp on mine planning and equipment selection. Bangkock, Thailand, pp 701-702

Parbhakar-Fox A, Lottermoser BG (2015) A critical review of acid rock drainage prediction methods and practices. Min Eng 82:107-124

Parbhakar-Fox A, Lottermoser B, Bradshaw D (2013) Evaluating waste rock mineralogy and microtexture during kinetic testing for improved acid rock drainage prediction. Min Eng 80:111-124

Prestia A, Bowell R, Warrender R, Barnes A, Lassiter D (2013) Environmental geochemistry of the Hycroft mine: a case study on the limitation of Sobek-style acid-generation predictions. Geochem Expl Environ Anal 13:171-182

Rimstidt J (1997) Quartz solubility at low temperatures. Geochim Cosmochim Acta 61:2553-2558

Roswell AJ, Rees MN, Suzcek CA (1979) Margin of the North American continent in Nevada during late Cambrian time. Am J Sci 279:14-33

Smith LJD, Neuner M, Gupton M, Moore M, Bailey BL, Blowes DW, Smith L, Sego DC (2009) Diavik waste rock project: from the laboratory to the Canadian Arctic. Proc, 8th ICARD, Skellefteá, Sweden, https://www.waterboards.ca.gov/academy/courses/ard/ day2/day2_sec5a_diavikwasterockprojectpaper.pdf

Stewart JH, Murchey BL, Jones DL, Wardlaw BR (1986) Paleontologic evidence for complex tectonic interlayering of Mississippian to Permian deep-water rocks of the Golconda Allochthon in the Tobin Range. North-Central Nevada Geol Soc Am Bull 97:1122-1132

Weber PA, Hughes JB, Conner LB, Lindsay P, Smart R (2006) Shortterm acid rock drainage characteristics determined by paste $\mathrm{pH}$ and kinetic NAG testing: Cypress Prospect, New Zealand. Proc, 7th ICARD, St. Louis, MO, https://doi.org/10.21000/jasmr06022 289

Wilson S (2010) Technical report for Allied Nevada Gold Corp. Hycroft Mine, Winnemucca, Nevada, USA. Scott E. Wilson Consulting, Englewood, CO, USA 